\title{
Why do Fund Managers Increase the Lottery-Like Characteristics of the Fund?
}

Minyeon Han ${ }^{* *}$, Investment Pool Advisory Team Leader, Mirae Asset Global Investments

Hyoung-goo Kang, Associate Professor, Hanyang University

Kyoung Hun Bae, Managing Director, Anchor Private Equity Partners

\begin{abstract}
$<$ Abstract $>$
We investigate why fund managers invest in lottery-like stocks and whether the behavior that holds more lottery-like stocks affects performance. First, mutual funds that hold more lottery stocks may attract more fund flows. Our results support the theory that fund managers invest more in lottery-like stocks to reflect investors' preferences for extreme payoffs. Second, the level of lottery-like characteristics of mutual funds does not predict managers' skill and performance. Therefore, fund managers holding more lottery stocks is not a result of managers' skills. Third, lottery-like characteristics of mutual funds do not significantly affect performance in specific reporting periods (e.g., year-end or quarter-end). Based on this result, we conclude that fund managers do not invest more in lottery stocks to advance their career.
\end{abstract}

Keywords: Lottery-Like Characteristic; Fund Flow; Manager Skill; Extreme Payoff; Career Concern

JEL Classification: G10, G11, G40

\footnotetext{
* This research was supported by Research Grant Program from the Korean Securities Association and FnGuide in 2018.

** Corresponding Author. Address: Investment Pool Advisory Team, Mirae Asset Global Investments, 16F, Tower 1, 33, Jong-ro, Jongno-gu, Seoul, Korea 03159; E-mail: yeonhan.min@gmail.com; Tel: +82-2-3774-5998; Fax: +82-2-3774-5964.
}

Received: October 31, 2019; Revised: September 21, 2020 \& June 3, 2021; Accepted: June 21, 2021 


\title{
왜 펀드 매니저들은 펀드의 복권성향을 증가시키는가?"
}

\author{
한 민 연 (미래에셋자산운용 투자풀자문팀장)** \\ 강 형 구 (한양대학교 부교수) \\ 배 경 훈 (Anchor Equity Partners 상무)
}

\begin{abstract}
본 연구는 펀드 매니저가 어떠한 동기로 극단적인 수익률 분포를 가진 복권성향적 주식(Lottery like stock)을 담아 펀드의 복권성향을 증가시키는지, 그리고 그 펀드의 복권성향은 향후 펀드의 성과에 어떠한 영향을 끼치게 되는지에 대해서 분석하였다. 실증분석 결과는 다음과 같다. 첫째, 펀드의 복권성향이 높을수록, 더 많은 펀드 플로우가 유입되었다. 이는 펀드의 복권성향을 나타내는 여러 측도를 사용했을 때에도 유사하게 나타났다. 추가적으로 복권성향이 높을수록 펀드들의 펀드 플로우-성과의 비선형적 관계가 더 크게 나타났다. 이러한 결과는 투자자들의 복권성향에 대한 선호를 반영하여 포트폴리오를 구성하는 것으로 볼 수 있다. 둘째, 펀드의 복권성향 수준은 펀드의 미래 성과와 매니저 스킬에 대해 유의미한 관계를 보이지 못했다. 셋째, 매니저의 평가 기간(연말 또는 분기말)에 펀드의 복권성향이 더 높게 나타나는 패턴은 확인할 수 없었다. 따라서 펀드 매니저는 커리어 우려(Career concern)로 인해 복권성향을 증가시키는 것은 아닌 것으로 판단할 수 있다. 본 연구는 투자자의 이해와 밀접하게 이어질 수 있는 펀드 복권성향 증가 행태에 대한 동기를 제시하였다는 점에서 시사점을 제공한다.
\end{abstract}

핵심 단어 : 복권성향, 펀드 플로우, 펀드 매니저 스킬, 극단적 수익률 분포, 커리어 우려

JEL 분류기호: G10, G11, G40

* 본 연구는 2018년 한국증권학회-FnGuide 연구지원사업으로 수행되었으며, FnGuide 자료를 사용하였습니다. 2019년도 춘계 증권학회에서 유익한 토론을 해주신 이준서 교수님께 감사의 말씀을 전합니다.

** 연락담당 저자. 주소: 서울시 종로구 종로33, Tower 1,16 층 미래에셋자산운용 투자풀자문팀, 03159; E-mail: yeonhan.min@gmail.com; Tel: 02-3774-5998; Fax: 02-3774-5964. 


\section{1. 서론}

낮은 가격, 높은 고유 변동성(idiosyncratic volatility), 높은 왜도(Skewness) 또는 고유 왜도(Idiosyncratic skewness) 등의 특성을 가진 복권 성향의 주식(Lottery-type stock)에 주로 투자하는 투자자는 주로 개인 투자자로 알려져 있다(Kumar, 2009; Han and Kumar, 2013). 기관 투자자들은 대부분의 경우 투자 유니버스가 한정되어 있고, 운용상의 제약이 있기 때문에 유니버스 밖에 있을 가능성이 높을 복권 성향의 주식에 함부로 투자하기 어려울 것이기 때문이다. 그러나 실제로 복권성향이 높을 것으로 예상되는 낮은 가격의 주식에 투자하는 저가주 펀드가 약진하고 ${ }^{1}$ 대중화됨을 고려하면, 국내 공모펀드들 사이에서도 복권 성향 주식에 대한 수요가 증가할 것으로 예상할 수 있다. Song and Park(2019)는 공모펀드 들은 시장의 5,000 원 이하 저가주 중 평균 $23.24 \%$, 대략 저가주 4 종목 중 1 종목을 편입 하고 있음을 보였다. 물론 펀드 순자산 대비 비중으로는 약 $2.6 \%$ 정도를 기록하는 것으로 나타나(p. 37) 적은 비중만 편입하고 있지만, 펀드 매니저들이 복권성향이 높을 가능성이 있는 여러 저가주 중 $1 / 4$ 을 편입하고 있다는 것을 알 수 있다. 그렇다면 1) 왜 펀드 매니저 들은 복권성향의 주식을 많이 편입함으로써 펀드의 복권성향을 증가시킬까? 그리고 2) 이러한 펀드의 복권성향 수준의 증가는 향후 성과에 어떠한 영향을 끼치는가? 이와 같은 질문에 대해서 살펴보는 것이 본 연구의 시작점이다.

펀드 매니저들이 복권성향적 주식을 편입함으로써 펀드의 복권성향을 크게 증가시키는 행태는 투자자들의 이해, 즉, 투자 성과와 직접적으로 연결될 수 있다. 만약 펀드 매니저가 특정한 전략에 기반하여 복권성향이 높은 주식들을 편입해 펀드의 복권성향을 증가시킨 결과가 좋은 성과를 가져온다면 투자자의 이해를 훼손하지는 않을 것이다. 기존 연구들 (Kacperczyk et al., 2005; Cremers and Petajisto, 2009; Amihud and Goyenko, 2013)에서 관측되고 있는 액티브한 펀드들의 좋은 성과를 고려할 때, 복권성향이 높은 종목을 편입하는 펀드 매니저의 전략을 좋은 성과를 가져올 수도 있다. 반면, 펀드 매니저의 커리어 우려 (Career concern)로 인한 펀드의 복권성향 수준의 확대라면, 투자자의 이해를 훼손할 수 있는 가능성이 있다. 펀드 매니저가 일반적인 방법으로 이번 분기 벤치마크를 달성하기 어려울 경우, 펀드의 복권성향을 크게 증가시켜 벤치마크를 초과하려는 인센티브가 있을 수 있다. 즉, 낮은 확률로 높은 성과를 거둘 수 있는 복권성향이 높은 주식의 편입을 늘려 포트폴리오의 복권성향을 증가시키는 일종의 '도박'과 같은 행태를 보일 수 있으며, 이는 향후 펀드의 성과에 좋지 않은 영향을 끼칠 수 있다. 예를 들어, 복권성향의 주식들은 낮은 위험 조정 기대 수익률을 기록할 가능성이 높다. 이는 투자자들이 복권성향의 주식을 선호 함으로써, 결국 이 주식들이 고평가되고 기대 수익률이 낮아지게 되기 때문이다(Brunnermeier et al., 2007; Barberis and Huang, 2008; Bali et al., 2011, 2017).

1) 파이낸셜투데이, 2015.02.10., “저가주 펀드 수익률 1위‥작은 고추가 맵다””. 
Why do Fund Managers Increase the Lottery-Like Characteristics of the Fund?

이처럼 1) 펀드 매니저들이 왜 펀드의 복권성향을 증가시키는지, 2) 펀드 복권성향의 증가는 향후 펀드 성과에 어떠한 영향을 끼치는지 등에 대해서 살펴보는 것은 중요한 문제이다. 그러나 최근 해외에서는 관련 연구들이 나타나며(Agarwal et al., 2020; Akbas and Genc, 2020; Goldie et al., 2019; Stein, 2019) 해당 이슈에 대한 관심이 증대되는 상황 임에도 불구하고, 국내에서의 연구 진행은 공모펀드의 저가주에 대해 연구한 Song and $\operatorname{Park}(2019)$ 를 제외하면 거의 없다. 본 연구를 시작으로 국내에서도 해당 이슈에 대한 연구 진행이 활발하게 될 것으로 기대한다.

시장 참여자들은 복권처럼 당첨된 확률은 낮으나, 만약 당첨되면 극단적인 양(+)의 수익률을 기록할 수 있는 복권 성향의 자산을 선호하고, 이것이 자산 가격에 반영되고 있음은 여러 연구에서 실증적으로 제시되고 있다(Harvey and Siddique, 2000; Mitton and Vorkink, 2007; Boyer et al., 2010; Bali et al., 2011, 2017). 이러한 복권성향의 주식을 투자자들이 선호하는 이유는 Brunnermeier et al.(2007)와 Barberis and Huang(2008)의 이론적 모형 으로부터 찾을 수 있다. Brunnermeier et al.(2007)은 투자자들의 왜도에 대한 선호가, 향후 미래의 좋은 상태(State)의 확률에 대해 투자자들이 매우 낙관하고 있기 때문에 나타나는 결과라고 주장했다. 결과적으로 이들도 양 $(+)$ 의 왜도를 가진 자산은 낮은 수익률을 보일 것이라 예측하였다. Barberis and Huang(2008)은 Tversky and Kahneman(1992)의 누적 전망 이론(Cumulative prospect theory)를 반영한 모델을 통해, 주식의 왜도가 가격에 영향을 끼칠 수 있음을 밝혔다. 누적 전망 이론에 따르면, 투자자는 손실이나 이익이 극단적인 상황에 더 높은 가중치를 부여하게 된다. 따라서 복권과 같은 극단적인 이익구조를 가진 자산을 선호하게 되어, 높은 양(+)의 왜도를 가진 복권성향의 주식들은 고평가 되고, 음(-)의 초과 수익률을 얻을 수 있다는 것이다.

복권성향의 주식들은 주로 개인 투자자들에 의해서 보유되고 거래되고 있는 것으로 알려져 있다(Kumar, 2009; Doran et al., 2011; Han and Kumar, 2013). 그러나 최근 연구들은 뮤추얼 펀드들도 복권성향의 주식을 편입할 가능성이 높음을 보여주었다. 예를 들어, Edelen et al.(2016)은 기관 투자자들이 잘 알려진 이상현상을 활용하지 못하고 오히려 반대로 투자 하는 경향이 있음을 보였다. 즉, 고평가된 주식들을 더 사는 경향을 보이고 있는 것이다. 이러한 행태는 차익거래의 제한(Limits of arbitrage)보다는 과도한 회전율 및 위험증가, 쏠림현상(Herding) 등의 대리인 이슈에 의한 것이라 주장했다. 따라서 펀드 매니저들도 고평가 되어있는 복권성향의 주식을 계속적으로 편입할 가능성도 있다.

그렇다면, 왜 펀드 매니저는 복권성향을 증가시키는 것인가? 첫 번째, 시장 참여자들이 펀드의 높은 복권성향을 선호하며(Akbas and Genc, 2020), 또는 복권 성향 주식을 편입 하는 것을 선호하기 때문에 발생하는 것일 가능성이 있다(Agarwal et al., 2020). 투자자 들이 보다 더 높은 복권성향을 보이는 펀드나 또는 더 많은 비중의 복권성향 주식을 담고 있는 펀드에 더 많은 자본을 배분한다면, 펀드 매니저들은 선호를 인지하고 더 많은 복권 성향 주식을 편입하게 될 인센티브가 존재한다. 실제로 투자자들의 복권성향이 높은 주식에 
한국증권학회지 제 50 권 6 호 (2021)

대한 선호가 발견되고 있음을 볼 때, 매니저는 더 많은 펀드 플로우가 유입되기를 기대하면서 복권성향 주식을 포트폴리오에 더 많이 편입하여 펀드의 복권성향을 증가시킬 수 있다. 그리고 만약 투자자들의 복권성향적 펀드에 대한 선호가 존재한다면, 복권성향이 높은 펀드 들의 펀드 플로우-성과 민감도는 복권성향이 낮은 펀드들의 펀드 플로우-성과 민감도보다 상대적으로 더 높게 나타날 것이다. 즉, 투자자들이 복권성향이 높은 펀드를 선호한다면 같은 크기의 성과 상승이 있을 때, 더 많은 펀드 플로우가 유입될 것으로 예상할 수 있다. 두 번째, 펀드의 높은 복권성향은 매니저의 스킬에 의한 결과일 수 있다. 즉, 펀드 매니저 들이 복권성향을 증가시키는 것은 매니저 본인들의 전략에 따른 것 일 수 있다. 마지막으로, 펀드 매니저의 커리어 우려로 인한 위험 증가(Risk shifting)의 일환으로 나타나는 결과일 가능성이 있다(Brown et al., 1996; Kempf and Ruenzi, 2007; Kempf et al., 2009). 즉, 극단적인 수익을 낼 수 있는 복권성향 주식에 대한 편입을 늘려 펀드의 복권성향 수준을 증가시킴으로써, 매니저는 평가 직전에 위험을 늘리고 자신의 성과를 높일 수 있기 때문 이다.

이와 같은 여러 가능성에 대해서 검증하기 위해서, 본 연구는 Agarwal et al.(2020), Akbas and Genc(2020) 등의 방법을 따라 펀드 포트폴리오 수준에서의 복권성향 수준에 대한 측도를 산출하고 분석을 실시한다. 직전 월의 최고 일별 수익률로 정의된 $M A X 1$ 를 복권성향 주식을 판단하는 기준으로 삼고(Bali et al., 2011), 펀드의 편입 종목들의 가중 평균한 $M A X 1^{H}$ 를 산출하여 포트폴리오 수준에서의 복권성향 수준으로 사용한다. 이후 구체 적으로 다음과 같은 분석을 실시한다. 첫째, 본 연구는 투자자들의 선호가 펀드 플로우(순 현금흐름)에 반영되는 것으로 간주하고(Barber et al., 2016; Berk and van Binsbergen, 2016, 2017), 펀드의 복권성향 수준이 펀드 플로우에 어떠한 영향을 끼치는지에 대해서 분석한다. 만약 펀드 매니저들이 투자자들의 높은 복권성향에 대한 선호를 반영하기 위하여 복권성향이 높은 주식들을 편입하여 펀드의 전체 복권성향을 늘렸다면, 펀드 플로우도 증가 하게 될 것이다. 그러나 실제로 펀드 투자자들이 쉽게 관측할 수 있는 것은 '펀드 수익률 자체에서 나타나는 복권성향'일 것이다. 따라서 직전 월의 최고 일별 펀드 수익률 $\left(M A X 1^{\text {Fund }}\right)$ 을 펀드 수익률의 복권성향을 측정하는 측도로 보고, 펀드 플로우와의 관계도 추가적으로 확인 한다. 이를 통해, 투자자들이 펀드 수익률의 극단적인 분포를 선호하고, 펀드 매니저들이 투자자들의 펀드의 복권성향에 대한 선호를 반영하고 있다는 것을 확인할 수 있을 것이다. 둘째, 펀드의 복권성향 수준이 실제로 미래의 펀드 성과와 어떠한 연관성이 있는가에 대해서 분석을 실시한다. 이를 통해, 펀드의 복권성향 수준이 미래성과에 대해 어떠한 방향의 예측력을 가지고 있는지에 대해서 살펴볼 것이다.

본 연구는 기존 연구들 중에서 펀드 매니저들이 왜 펀드의 복권성향을 증가시키는지에 대해 살펴본 Agarwal et al.(2020)과 Akbas and Genc(2020)의 연구와 유사한 점이 있다. 먼저 Akbas and Genc(2020)는 주로 투자자들이 실제로 펀드 수익률의 극단적인 분포에 대해서 선호하는 모습을 보이는가에 대해서 살펴보았다. 그에 비해 Agarwal et al.(2020)은 
Why do Fund Managers Increase the Lottery-Like Characteristics of the Fund?

펀드 매니저들이 왜 높은 복권성향의 주식들을 편입하는 지에 대해서 연구하였다. 반면 본 연구는 다음과 같은 점에서 두 연구와 차이가 있다. 첫째, 본 연구는 왜 펀드 매니저들은 펀드의 복권성향을 높게 가져가는지, 그리고 실제로 펀드 투자자들이 높은 복권성향을 가진 펀드에 더 많은 자본을 투입하는지를 모두 살펴보았다. 둘째, 본 연구는 펀드 매니저가 펀드의 복권성향을 높게 하려는 이유에 대해서, 추가적으로 펀드 매니저의 펀드 플로우-성과 민감도의 볼록성이 영향을 끼칠 수 있음을 분석하였다. 이는 기존 연구들에서는 확인하지 않았던 부분이다.

본 연구의 결과를 요약하면 다음과 같다. 첫째, 펀드의 복권성향 수준이 높을수록, 펀드 플로우는 높게 나타났다. 과거 성과 및 여러 통제변수들을 통제한 고정효과 패널 회귀분석 에서 펀드의 복권성향 수준을 나타내는 여러 변수들은 모두 익월의 펀드 플로우에 대해서 유의한 양(+)의 관계를 나타냈다. 그리고 펀드 수익률을 기반으로 측정한 복권성향 $\left(M A X 1^{\text {Fund }}\right)$ 이 높을수록, 익월의 펀드 플로우는 높은 것으로 나타났다. 즉, 투자자들은 극단적인 수익률의 분포가 나타나는 펀드를 선호하고 있는 것을 알 수 있다. 이 결과를 볼 때, 펀드 매니저가 높은 복권성향에 대한 투자자들의 선호를 반영하여 펀드의 복권성향을 높이는 방향으로 포트폴리오를 구성하고 있음으로 추정할 수 있다. 둘째, 펀드의 복권성향이 높은 집단이 낮은 집단보다 펀드 플로우-성과의 볼록성이 더 크게 나타났다. 예를 들어, 펀드의 복권 성향이 높은 집단에서 성과가 높은 경우와 낮은 경우의 펀드 플로우의 차이가 가장 크게 나타났다. 즉, 펀드 매니저는 투자자들이 선호를 반영하여 복권성향을 증가시킴으로써, 같은 크기의 성과 증가에도 더 많은 펀드 플로우를 얻을 수 있게 된다. 셋째, 펀드의 복권성향 수준과 Carhart(1997) 4요인 모형으로 추정한 펀드 성과는 유의한 관계가 존재하지 않았다. 그리고 Berk and van Binsbergen(2015)의 방법으로 산출한 매니저의 스킬은 펀드의 복권 성향 수준에 대한 예측력이 없었다. 따라서 펀드 매니저가 펀드의 복권성향을 증가시키는 것은 매니저의 스킬에 기인한 것이라고 볼 수 없었다. 넷째, 펀드 매니저가 펀드의 복권성향을 증가시키는 것은, 펀드 매니저의 커리어 우려를 위해 위험을 증가시킨다는 가설로는 설명 되기 어려웠다. 펀드 매니저의 평가가 집중된 연말이나 분기말에 펀드 복권성향 수준이 높아지는 등의 계절성은 발견되지 않았다. 또한 상반기(또는 전 분기)의 펀드 성과와 하반기 (또는 다음 분기)의 복권성향과는 유의미한 관계가 발견되지 않았다.

마지막으로 본 연구 결과에 대한 대안적 설명(Alternative explanation)에 대한 추가 분석을 수행하였으나 결과는 유사하게 나타났다. 첫 번째는 펀드의 복권성향 수준과 펀드 플로우와의 양(+)의 상관관계가 복권성향에 대한 선호 때문이 아니라, 높은 복권성향으로 인해 투자자 들에게 인지도(Visibility)가 증가하여 발생한 것이라는 대안적 설명에 대한 것이다. 투자자 들의 의사 결정에서 인지도는 중요하며(Gervais et al., 2001; Barber and Odean, 2008), 따라서 펀드가 투자자들의 눈에 띄게 되는 것은 펀드 플로우가 증가하는 원인이 될 수도 있다. 그러나 펀드 및 운용사의 규모, 펀드 평가사의 운용사 평가 등급을 인지도에 대한 대용 변수로 활용하여 분석한 결과, 인지도가 높은 집단에서 펀드 복권성향-펀드 플로우의 관계가 
한국증권학회지 제 50 권 6호 (2021)

더 크게 나타났다. 따라서 펀드의 복권성향과 펀드 플로우의 양(+)의 관계는 복권성향에 대한 투자자들의 선호가 반영된 것으로 보는 것이 더 적절한 해석이다. 두 번째 추가분석은 $\mathrm{MAX}$ 기반의 복권성향 측정 변수가 아닌 다른 변수를 사용한 분석이다. 복권성향적 주식의 대표적인 성격으로 볼 수 있는 높은 왜도와 변동성르를 추가적인 복권성향 변수로 사용하여 본 연구 결과의 강건성을 확인하였다. 추가분석 결과, $\mathrm{MAX}$ 기반의 복권성향 측정 변수로 얻은 결과와 유사한 결과를 얻어 강건성을 확인하였다.

본 연구가 제시하는 시사점은 어떠한 동기에 의해서 펀드 매니저들이 펀드의 복권성향을 증가시키는지에 대해서 밝혔다는 점이다. 본 연구의 결과를 통해서, 복권성향 주식에 대한 투자가 펀드의 높은 복권성향에 대한 고객의 선호를 반영한 것인지, 매니저의 주식 선택 능력에 의한 것인지, 아니면 매니저 자신의 커리어 우려로 인한 위험 증가의 한 형태인지 등을 파악할 수 있었다. 추가적으로, 실제로 복권성향 주식에 대한 투자를 증가시키면 펀드의 성과에 어떠한 영향을 끼치는 지에 대해서도 살펴볼 수 있었다.

본 연구는 다음과 같은 순서로 진행될 것이다. 제 2장에서는 데이터와 변수에 대한 설명을, 제 3 장에서는 여러 실증분석의 결과와 그에 대한 해석을 제시한다. 제 4장에서는 추가분석을 제시하며, 마지막 제 5장에서는 결론을 맺는다.

\section{2. 데이터 및 변수 설명}

\section{1 데이터}

본 연구는 KG Zeroin에서 제공하는 2005년 3월부터 2018년 9월까지의 국내의 공모 액티브(Active) 주식형 펀드를 대상으로 분석을 실시한다. 주식 편입 비율이 $60 \%$ 이상의 펀드만을 표본에 포함하며, 인덱스 펀드 등 패시브(Passive) 또는 혼합형 펀드, 채권형 펀드는 분석에서 제외한다. 최종적으로 사용되는 펀드 관련 변수는 개별 펀드의 수익률, 그리고 각 펀드별 보수 및 선취, 후취 수수료, 펀드 최초 설정일자, TNA(순자산, Total net asset), 운용사 정보, 분기별로 공시되는 각 펀드 별 포트폴리오 구성 종목 등이다. 공모 펀드 중 멀티 클래스(Multi class)는 수수료(Load) 및 보수(Fee)의 체계만 다를 뿐 실질적으로 하나의 펀드로 운용되는 것이다. 따라서 이 경우, TNA(Total net asset)을 기준으로 펀드들의 수익률 및 보수를 가중 평균하여 하나의 펀드로 사용한다

본 연구에서는 극단치로 발생할 수 있는 여러 편의를 제거하기 위해서 다음과 같은 조치를 취한다. 먼저 펀드 패밀리 또는 운용사들의 인큐베이션 전략으로 인한 편의를 제거하기 위해서, 본 연구는 최소 출시 후 1 년 이상이 지난 펀드들만 표본에 포함을 한다(Evans, 2010). 또한 규모가 너무 작아 실질적으로 효율적으로 운용이 불가능한 소규모 펀드들을

2) Kumar(2009)는 복권의 특징을 (1) 높은 잠재적인 이익에 비해 낮은 가격, (2) 수익 분포의 극단적인 분산, (3) 수익을 얻을 확률이 극단적으로 낮은, 즉, 양(+)의 왜도를 가진 것으로 정의하였다. 
Why do Fund Managers Increase the Lottery-Like Characteristics of the Fund?

제거하기 위해서, 30억 미만의 $\mathrm{TNA}$ 를 기록하는 펀드는 표본에서 제외한다. 마지막으로, 각 변수들은 각 연도별로 상위 $1 \%$ 와 하위 $99 \%$ 기준으로 윈저화(Winsorization)을 실시 하여 극단치를 제거하였다.

추가적으로 개별 주식들에 대한 데이터는 Fnguide에서 제공하는 2005년 3월부터 2018년 9월까지 유가증권시장과 코스닥에 한번이라도 상장되었던 종목들을 대상으로 한 데이터를 사용한다. 이 데이터를 대상으로 개별 주식들의 복권성향적 성격을 파악하고, 펀드들의 포트 폴리오 수준의 복권성향을 파악한다. 무위험 수익률은 Call 금리를 사용하며, 시장 수익률은 KOSPI 지수를 사용한다. 데이터 출처에 대한 자세한 내용은 <표 1>을 참고하라.

〈표 1〉변수 설명

<표 1>에서는 본 연구에서 사용한 변수들에 대한 자세한 설명 및 자료 출처를 제시하였다. 펀드의 수익률 및 기타 특성에 대한 데이터는 KG Zeroin에서, 나머지 데이터는 FnGuide에서 제공받았다

\begin{tabular}{|c|c|c|c|}
\hline 분류 & 변수명 & 설명 & 출처 \\
\hline \multirow[t]{10}{*}{ 복권성향 } & $M A X 1^{H}$ & $\begin{array}{l}\text { 각 펀드 편입종목들의 월별 최고 수익률(Bali et al., 2011)을 } \\
\text { 가중 평균 }\end{array}$ & Fnguide \\
\hline & $M A X 5^{H}$ & $\begin{array}{l}\text { 각 펀드 편입종목들의 월별 최고 수익률을 기록한 5일의 } \\
\text { 평균 수익률(Bali et al., 2011)을 가중 평균 }\end{array}$ & Fnguide \\
\hline & $M A X 10^{H}$ & $\begin{array}{l}\text { 각 펀드 편입종목들의 월별 최고 수익률을 기록한 } 10 \text { 일의 } \\
\text { 평균 수익률(Bali et al., 2011)을 가중 평균 }\end{array}$ & Fnguide \\
\hline & $M A X 1^{\text {Fund }}$ & 펀드 수익률의 월별 최고 수익률 & KG Zeroin \\
\hline & $M A X 5^{\text {Fund }}$ & 펀드 수익률의 월별 최고 수익률을 기록한 5일의 평균 수익률 & KG Zeroin \\
\hline & $M A X 10^{\text {Fund }}$ & 펀드 수익률의 월별 최고 수익률을 기록한 10일의 평균 수익률 & KG Zeroin \\
\hline & $M A X 1^{\text {Prop }}$ & 펀드 별 Top 오분위 $M A X 1$ 종목들의 편입비중 & Fnguide \\
\hline & MAX $5^{\text {Prop }}$ & 펀드 별 $\mathrm{Top}$ 오분위 $M A X 5$ 종목들의 편입비중 & Fnguide \\
\hline & MAX $10^{\text {Prop }}$ & 펀드 별 Top 오분위 $M A X 10$ 종목들의 편입비중 & Fnguide \\
\hline & Lottery Index & Bali et al. (2018)의 방법을 사용한 복권주식 성향 스코어 & Fnguide \\
\hline $\begin{array}{l}\text { 펀드 } \\
\text { 플로우 }\end{array}$ & FundFlow & $\begin{array}{l}\text { 펀드플로우(Sirri and Tufano, 1998; Del Guercio and Tkac, } \\
\text { 2002) }\end{array}$ & KG Zeroin \\
\hline \multirow{4}{*}{$\begin{array}{l}\text { 성과 및 } \\
\text { 스킬 }\end{array}$} & Alpha 4 & 펀드의 Carhart(1997) 4요인 초과성과 & KG Zeroin \\
\hline & Alpha 3 & 펀드의 Fama and French(1993) 3요인 초과성과 & KG Zeroin \\
\hline & Rtn & 펀드 보수 차감 후 수익률 & KG Zeroin \\
\hline & Skill & Berk and van Binsbergen(2015)의 매니저 스킬 관련 측도 & KG Zeroin \\
\hline \multirow{7}{*}{$\begin{array}{l}\text { 기타 } \\
\text { 통제 } \\
\text { 변수 }\end{array}$} & FundSize & 펀드 Total Net Asset의 자연 로그 값 & KG Zeroin \\
\hline & Vol & 과거 펀드 변동성(36개월) & KG Zeroin \\
\hline & $\mathrm{TR}^{2}$ & $\begin{array}{l}\text { 펀드 액티브니스(Activeness): 펀드 수익률의 Carhart } 4 \\
\text { 요인 모델에서의 } R^{2} \text { (Amihud and Goyenko, 2013) }\end{array}$ & KG Zeroin \\
\hline & FamSize & $\begin{array}{l}\text { 운용사의 해당 자산군에 대한 공모펀드 AUM(Asset under } \\
\text { management)의 총합의 로그 값 }\end{array}$ & KG Zeroin \\
\hline & Age & 펀드 운용연수의 로그 값 & KG Zeroin \\
\hline & Load & 펀드 수수료가 존재하면 1 , 아니면 0 인 더미 변수 & KG Zeroin \\
\hline & Fee & 펀드보수 & KG Zeroin \\
\hline
\end{tabular}




\section{2 변수 설명}

\subsection{1 펀드의 복권성향 관련 변수}

펀드 수준에서의 복권성향을 파악할 수 있는 변수로, 본 연구에서는 Agarwal et al. (2020)의 방법을 따라 Bali et al.(2011)이 제안한 MAX를 사용한다. Bali et al.(2011)은 전 월의 최고 일별 수익률이 높은 주식일수록 향후 위험 조정 기대 수익률이 낮게 나타 남을 보이고, 이는 극단적으로 높은 수익을 얻을 수 있는 주식, 즉, 복권성향의 주식에 대해 투자자들이 높은 수요를 보임으로써 나타나는 현상이라고 주장했다. 먼저 $M A X$ 의 정의는 아래와 같다.

$$
\operatorname{MAX}{ }_{j, t}=\operatorname{Max}\left(R_{j, d}\right), d=1,2 \ldots .21
$$

본 연구에서는 전 월 동안의 가장 높은 수익률을 기록한 1 일(또는 5 일과 10 일)의 평균 수익률을 $M A X 1$ (MAX5, MAX10)으로 정의하고, 이를 복권성향 주식에 대한 대용변수로 사용한다. 펀드 포트폴리오 수준에서의 복권성향을 파악하기 위해서, 펀드가 보유한 종목 들의 가중치를 활용하여 펀드 수준에서의 월별 가중평균 $M A X 1$ 을 산출한다. 전 월의 최고 수익률을 사용하는 $M A X 1^{H}$ 의 경우는 식 (2)과 같이 산출한다.

$$
\operatorname{MAX} 1_{f, t}^{H}=\sum_{1}^{N} \omega_{f, i, t} \times M A X 1_{i, t}
$$

이때, $\mathrm{t}$ 시점을 기준으로 가장 최근에 발표된 포트폴리오 정보를 활용하여 가중치를 산출한다. 따라서 펀드가 높은 $M A X 1$ 값을 가진 복권성향이 높은 종목들을 많이 편입 한다면, 펀드의 복권성향을 나타내는 $M A X 1^{H}\left(M A X 5^{H}, M A X 10^{H}\right)$ 의 값은 크게 나타날 것이다.

펀드의 복권성향을 나타낼 수 있는 두 번째 변수로 본 연구에서는 펀드 수익률의 복권 성향을 사용한다. 펀드 매니저가 복권성향이 높은 종목을 많이 편입하게 되면, 펀드의 복권 성향 $\left(M A X 1^{H}\right)$ 이 증가하게 될 것이며, 따라서 펀드 수익률의 복권성향도 증가하게 될 가능 성이 높다. 역시 마찬가지의 방법으로, 본 연구에서는 전월 동안의 가장 높은 수익률을 기록한 1 일(또는 5 일과 10 일)의 평균 펀드 수익률을 펀드 수익률의 복권성향 $\left(M A X 1^{F u n d}\right)$ 으로 사용 한다. 추가적으로, 펀드의 복권성향을 파악하는 다른 측도로 다음의 변수들을 사용한다. 먼저, 펀드가 높은 $M A X 1$ 값을 가지고 있는 종목을 얼마나 편입하고 있는가를 살펴보는 $M A X 1^{\text {Prop }}$ 을 사용한다. $M A X 1^{\text {Prop }}$ 은 각 월 별로 종목들의 $M A X 1$ 를 십분위(Decile)로 분류하고, $M A X 1$ 값이 상위 8,910 십분위에 있는 주식들을 해당 펀드가 얼마나 편입하고 있는 지 비중을 나타낸 것이다. 즉, 펀드가 복권 성향이 높은 종목들을 많이 편입하고 있다면, $M A X 1^{\text {Prop }}$ 도 역시 큰 값을 나타내게 될 것이다. 마찬가지로, 역시 $M A X 5^{\text {Prop }}, M A X 10^{\text {Prop }}$ 도 같은 방법으로 적용하여 사용한다. 추가적으로, LotteryIndex 을 사용한다. LotteryIndex 는 
Why do Fund Managers Increase the Lottery-Like Characteristics of the Fund?

Bali et al. $(2018)^{3)}$ 의 방법을 따라서 산출한다.

\subsection{2 펀드 플로우, 성과 및 스킬 관련 변수}

본 연구에서는 펀드에 대한 투자자들의 반응을 나타내는 변수로 펀드의 플로우(순현금 흐름)을 사용한다(Berk and van Binsbergen, 2016, 2017). 펀드 플로우는 KG Zeroin에서 제공하는 실제 펀드의 매월 유출입 금액을 사용하여, 이를 전월의 펀드 순자산총액(TNA)로 나누어 사용한다. 본 연구에서 펀드의 성과 관련 지표는 크게 두 가지를 사용한다. 1) Fama and French(1993) 3요인 모형 조정 수익률, 2) Carhart(1997) 4요인 모형 조정 수익률이다. 요인 모형에서 산출되는 알파 수익률은 다음과 같은 방식으로 산출한다. 첫째, 지난 36 개월의 수익률 데이터를 통해, 펀드 수익률과 회귀분석을 실시하고 각 요인들의 회귀계수를 구한다. 이때, $\mathrm{t}$ 일부터 최근 데이터가 30 개월 이상 확보된 표본인 경우만 회귀 분석을 실시한다. 둘째, 산출된 회귀 계수와 $\mathrm{t}+1$ 기에 실현된 요인 수익률을 곱하여 위험 조정 기대 수익률을 구하고, 이 위험 조정 기대 수익률과 실현된 펀드 수익률(펀드의 무위험 이자율인 Call 금리 초과 수익률)의 차이를 알파로 정의한다. 각 요인 수익률은 Fnguide에서 제공하는 데이터를 사용한다. 각 요인 모형에서 알파 수익률을 산출하는 자세한 방법은 아래와 같다.

$$
\begin{gathered}
\alpha_{i, t+1}^{F F 3}=r_{i, t+1}-\hat{\beta}_{M K T, i, t} M K T_{t+1}-\hat{\beta}_{S M B, i, t} S M B_{t+1}-\hat{\beta}_{H M L, i, t} H M L_{t+1} \\
\alpha_{i, t+1}^{\text {Carhart }}=r_{i, t+1}-\hat{\beta}_{M K T, i, t} M K T_{t+1}-\hat{\beta}_{S M B, i, t} S M B_{t+1}-\hat{\beta}_{H M L, i, t} H M L_{t+1}-\hat{\beta}_{U M D, i, t} U M D_{t+1}
\end{gathered}
$$

KG Zeroin에서 제공하는 스타일은 학계의 일반적인 스타일(규모-가치) 구분과는 다르게, 일반, 중소형, 배당 스타일 등으로 구분되어 있다. 이를 보완하고 펀드의 정확한 스타일 구분을 위해서, 본 연구는 다음과 같은 방법을 적용한다. 첫째, 매 월마다 초과 성과를 산출할 때 사용한 회귀분석에서의 회귀계수를 산출한다. 둘째, 이 회귀계수들의 크기를 기준으로 각각 삼분위로 나누어 스타일을 구분한다. 예를 들어, $\mathrm{SMB}$ 의 회귀계수를 기준으로 나눈 다면, 가장 큰 회귀계수를 가지고 있는 펀드들은 소형, 그 이후는 중형, 대형으로 구분이 될 것이다. 규모와 가치, 모멘텀 요인들의 회귀계수를 통해서 독립적으로 삼분위로 구분을 하고, 각 스타일 구분을 서로 교차하여 최종적으로 $3 \times 3 \times 3=27$ 개의 스타일로 구분하게 된다.

3) Bali et al.(2018)은 주가(PRC)과 고유 변동성(Idiosyncratic Volatility, IVOL), 그리고 고유 왜도 (Idiosyncratic Skewness, ISKEW)를 조합하여 복권 성향 주식에 대한 지수(Lottery index)를 구성 하였다. 구성 방법은 다음과 같다. 첫째, 매월 말 PRC를 기준으로 오십분위로 나누며, 이때 낮은 주가일수록 높은 분위에 속하도록 분류한다. 마찬가지로 IVOL과 ISKEW도 오십분위로 나누며, 이때는 높은 값을 가질수록 높은 분위에 속하도록 분류한다. 마지막으로 각각의 세 가지 지표들의 순위를 더해서 최종적으로 복권성향 지수(Lottery index)를 만든다. 이 값은 최소 3에서 최대 150 까지의 값을 가지게 되며, 높을수록 그 주식은 복권 성향을 가지고 있는 주식이라 할 수 있다. 본 연구에서는 이 복권성향 지수를 150 으로 나누어 사용한다. 
한국증권학회지 제 50 권 6호 (2021)

본 연구에서는 펀드 매니저의 스킬에 대한 변수로는 Berk and van Binsbergen(2015)의 'Value Added'를 고려한다. 펀드의 성과는 온전히 매니저의 스킬에 의해서 결정되지 않는다. 시장에서의 경쟁으로 인해 새로운 투자기회는 점차 줄어들게 되고, 스킬이 있는 매니저라 해도 지속적으로 성과를 창출하기 어렵다. 또한 매니저의 스킬이 존재하여 좋은 성과를 내고 있다면, 점차 그 펀드로 자금이 추가적으로 유입되고 규모가 커져 규모의 불경제가 나타나게 될 것이다(Berk and Green, 2004). 따라서 궁극적으로 펀드가 벤치마크 대비 얻을 수 있는 수익률은 0까지 낮아지게 되는 것이다(Berk and van Binsbergen, 2015; Pástor et al., 2015). 이러한 결과에 기인하면 펀드의 성과보다는, 실질적으로 펀드 매니저가 얼마나 펀드에 추가적인 가치를 가져다 줄 수 있는가에 대한 측도인 'Value Added'가 매니저의 스킬 보유 여부를 파악하는데 있어서 더 유용할 것이다. 이를 위해서, Berk and van Binsbergen(2015)을 따라서 t기의 펀드의 보수 차감 전 수익률과 벤치마크 수익률과의 차이를 t-1기의 TNA와 곱한 값을 스킬(Skill)로 사용한다. 벤치마크 수익률로는 앞에서 제시한 성과 지표 중 Carhart 4요인 모형의 벤치마크 수익률을 사용한다. ${ }^{4)}$ Value added 산출 시 사용한 TNA는 2001년을 기준으로 인플레이션을 조정한 값이다. 이때 과거 36개월 동안의 평균 Value added를 매니저의 스킬에 대한 대용치로 사용한다.

기타 제반 통제변수로는 펀드 규모(FundSize), 운용사 AUM 규모(FamSize), 펀드의 운용 연수(Age), 과거 36개월 간 펀드 수익률 변동성(Vol), 펀드의 요인 모형에서의 $\mathrm{R}^{2}\left(\mathrm{TR}^{2}\right)$, 그리고 수수료(Load)와 펀드 보수(Expense) 등을 고려한다. FundSize와 FamSize, Age는 모두 자연로그를 위한 값을 사용한다. 펀드의 액티브니스(Activeness)를 파악하고자, Amihud and Goyenko(2013)의 연구를 따라서 요인 모형에서의 $R^{2}$ 를 사용한다. Amihud and Goyenko(2013)는 벤치마크 다요인 모형에서의 $\mathrm{R}^{2}$ 가 낮을수록, 즉, 펀드 수익률의 변화가 요인으로 설명되는 부분이 낮을수록, 펀드는 더 액티브하게 운용하며 더 높은 초과 성과를 낸다는 것을 밝혔다. $\mathrm{R}^{2}$ 는 0 과 1 사이의 값으로 그 분포가 음으로 치우쳐 있으므로, 본 연구에서는 아래와 같이 Amihud and Goyenko(2013)가 제안한 방법으로 $\mathrm{R}^{2}$ 를 로직스틱 (Logistic) 변환한 값을 변수로 사용한다. 아래에서 $\mathrm{n}$ 은 관측치 수로, 본 연구에서는 36 을 사용한다.

$$
T R^{2}\left(\text { Transformed } R^{2}\right)=\log \left(\left(\sqrt{R^{2}}+n / 2\right) /\left(1-\sqrt{R^{2}}+\mathrm{n} / 2\right)\right)
$$

4) Fama and French(1993) 3요인 모형이나 Carhart(1997) 4요인 모형은 실제로 펀드가 투자 또는 복제하기 어렵기 때문에, 대안적 투자 기회(Alternative investment opportunity set)라는 벤치마크의 정의에서는 적합하지 않을 수 있다. Berk and van Binsbergen(2015)은 이를 해결하기 위해서 Vanguard 사에서 운용하는 다양한 인덱스 펀드(Index fund)들을 대안적인 투자 기회로 삼고 벤치 마크 수익률을 만들었다. 그러나 이를 국내에서 바로 적용하기에는 무리가 있다. 미국과 달리 국내의 인덱스 펀드 또는 ETF(Exchange Traded Fund)들은 대부분 기초자산이 KOSPI 200인 경우가 많으며, 가치나 성장, 소형주 ETF가 존재하더라도 그 규모나 거래량이 높지 않아 실제로 대안적인 투자기회, 벤치마크로 사용하기에는 무리가 있다. 
Why do Fund Managers Increase the Lottery-Like Characteristics of the Fund?

Load는 펀드가 선취나 후취 수수료를 부과하는 경우는 1 , 아니면 0 인 더미변수이며, Expense는 펀드의 총 보수이다.

\section{3 기초 통계량}

<표 2〉는 본 연구에서 고려된 변수들의 기초 통계량을 나타낸 것이다. 먼저 $M A X 1^{H}$ 와 $M A X 5^{H}, M A X 10^{H}$ 의 평균은 각각 약 $4.64 \%$, 그리고 $2.82 \%$ 와 $1.76 \%$ 정도로 나타났다. 예를 들어, $4.64 \%$ 는 펀드 보유 종목들의 한 달 동안 가장 높은 수익률을 기록한 일일 수익률의 평균이 4.64\%라는 것이다. 이는 Agarwal et al.(2020)에서 산출한 평균 $M A X 1^{H}(4.58 \%)$ 와 비교했을 때 비슷한 결과라고 할 수 있다. 펀드 성과지표를 살펴보면, Fama-French(1993)의 3요인 모형을 고려한 Alpha3와 Carhart(1997)의 모멘텀 요인을 추가 고려한 초과성과인 Alpha4 모두에서 양(+)의 값을 보이고 있음을 알 수 있다. Berk and van Binsbergen(2015)의 스킬 측도(Value added)는 평균 0.849 (억 원)으로 나타나, 국내에서 공모펀드는 월 평균 8,490 만 원 정도의 추가적인 가치를 창출하고 있는 것으로 파악할 수 있다. 〈표 2 >의 마지막

\section{〈표 2〉기초 통계량}

본 연구에서 사용된 변수들의 기초 통계량을 나타낸 것이다. Q1, MED, MEAN, Q3, STD, NOBS는 각각 1 사분위값, 중앙값, 평균, 3 사분위값, 표준편차, 관측치 수를 나타낸 것이다. $\mathrm{COR}$ 는 $M A X 1^{H}$ 와 다른 변수들 간의 상관관계 계수를 나타낸 것이다. 각 변수들에 대한 자세한 설명은 <표 1>을 참고하라.

Panel A: 기초 통계량

\begin{tabular}{|c|c|c|c|c|c|c|c|}
\hline & Q1 & MED & MEAN & Q3 & STD & NOBS & $\mathrm{COR}$ \\
\hline$M A X 1^{H}(\%)$ & 3.73 & 4.34 & 4.64 & 5.24 & 1.43 & 36,001 & \\
\hline$M A X 5^{H}(\%)$ & 2.24 & 2.63 & 2.82 & 3.18 & 0.88 & 36,001 & $0.98^{* * *}$ \\
\hline$M A X 10^{H}(\%)$ & 1.38 & 1.65 & 1.76 & 2.00 & 0.58 & 36,001 & $0.95^{* * *}$ \\
\hline$M A X 1^{\text {Fund }}(\%)$ & 1.28 & 1.74 & 2.06 & 2.42 & 1.29 & 36,001 & $0.77^{* * *}$ \\
\hline$M A X 5^{\text {Fund }}(\%)$ & 0.87 & 1.15 & 1.33 & 1.57 & 0.71 & 36,001 & $0.81^{* * *}$ \\
\hline MAX10 Fund $(\%)$ & 0.56 & 0.76 & 0.86 & 1.00 & 0.45 & 36,001 & $0.81^{* * *}$ \\
\hline$M A X 1^{\text {Prop }}(\%)$ & 4.68 & 9.31 & 11.43 & 15.85 & 9.38 & 36,001 & $0.45^{* * *}$ \\
\hline$M A X 5^{\text {Prop }}(\%)$ & 6.92 & 13.11 & 15.26 & 21.08 & 11.06 & 36,001 & $0.46^{* * *}$ \\
\hline MAX $10^{\text {Prop }}(\%)$ & 9.49 & 16.8 & 19.17 & 25.83 & 12.85 & 36,001 & $0.43^{* * *}$ \\
\hline Lottery Index & 0.274 & 0.302 & 0.304 & 0.332 & 0.0500 & 36,001 & $0.31^{* * *}$ \\
\hline FundFlow $(\%)$ & -2.73 & -0.66 & -0.45 & 0.04 & 8.60 & 35,775 & $0.11^{* * *}$ \\
\hline Alpha 4(\%) & -1.02 & 0.23 & 0.24 & 1.45 & 1.99 & 27,067 & $0.03^{* * *}$ \\
\hline Alpha 3(\%) & -0.94 & 0.29 & 0.35 & 1.56 & 2.05 & 27,067 & $0.05^{* * *}$ \\
\hline Skill & -0.2344 & 0.0238 & 0.8494 & 0.3941 & 11.053 & 27,067 & $0.06^{* * *}$ \\
\hline FundSize & 22.43 & 23.58 & 23.84 & 25.11 & 1.98 & 35,775 & $0.02^{* * *}$ \\
\hline $\operatorname{Vol}(\%)$ & 10.97 & 17.26 & 17.43 & 22.80 & 6.68 & 27,067 & $0.28^{* * *}$ \\
\hline $\mathrm{TR}^{2}$ & 1.93 & 2.45 & 2.34 & 2.81 & 0.63 & 27,067 & $0.12^{* * *}$ \\
\hline FamSize & 26.32 & 27.57 & 27.35 & 28.57 & 1.83 & 36,001 & $0.03^{* * *}$ \\
\hline Age & 7.11 & 7.73 & 7.49 & 8.12 & 0.91 & 36,001 & $-0.16^{* * *}$ \\
\hline Load & 0.00 & 1.00 & 0.56 & 1.00 & 0.50 & 36,001 & 0.01 \\
\hline Fee & 1.18 & 1.46 & 1.43 & 1.76 & 0.45 & 36,001 & $0.08^{* * *}$ \\
\hline
\end{tabular}


한국증권학회지 제50권 6호 (2021)

〈표 2〉기초 통계량(계속)

Panel B: 연도별 펀드 복권성향 추이

\begin{tabular}{lcccccccc}
\hline YEAR & NOBS & $M_{A X 1^{H}}$ & $M A X 5^{H}$ & $M A X 10^{H}$ & $M^{H} 1^{\text {Prop }}$ & MAX $^{\text {Prop }}$ & MAX10 $^{\text {Prop }}$ & Lot Index \\
\hline 2005 & 139 & 4.36 & 2.72 & 1.76 & 2.74 & 5.65 & 7.82 & 25.89 \\
2006 & 168 & 4.06 & 2.51 & 1.58 & 3.72 & 5.67 & 9.29 & 27.91 \\
2007 & 202 & 5.74 & 3.54 & 2.25 & 10.71 & 18.91 & 25.17 & 31.15 \\
2008 & 212 & 6.32 & 3.88 & 2.37 & 12.56 & 15.20 & 20.19 & 28.99 \\
2009 & 227 & 5.55 & 3.47 & 2.26 & 6.47 & 11.08 & 15.44 & 27.37 \\
2010 & 250 & 4.44 & 2.75 & 1.75 & 6.93 & 12.14 & 16.61 & 29.16 \\
2011 & 274 & 5.39 & 3.32 & 2.08 & 11.03 & 17.92 & 24.09 & 30.25 \\
2012 & 269 & 4.05 & 2.53 & 1.59 & 6.01 & 10.19 & 14.47 & 27.55 \\
2013 & 260 & 3.76 & 2.23 & 1.38 & 9.46 & 12.57 & 15.40 & 29.41 \\
2014 & 266 & 3.87 & 2.30 & 1.40 & 12.95 & 16.04 & 18.40 & 31.39 \\
2015 & 264 & 5.24 & 3.06 & 1.88 & 16.71 & 18.18 & 19.87 & 32.87 \\
2016 & 251 & 4.00 & 2.37 & 1.45 & 13.95 & 15.59 & 19.30 & 32.45 \\
2017 & 230 & 3.88 & 2.29 & 1.42 & 21.22 & 25.77 & 30.29 & 33.92 \\
2018 & 226 & 4.48 & 2.63 & 1.59 & 19.84 & 22.40 & 25.24 & 34.65 \\
\hline
\end{tabular}

$\mathrm{COR}$ (Correlation) 열은 $M A X 1^{H}$ 와 다른 변수들 간의 상관관계를 나타낸 것이다. 결과를 살펴보면 다음과 같다. 먼저 펀드의 $M A X 1^{H}$ 은 펀드 플로우(FundFlow), 성과(Alpha4, Alpha3) 및 매니저 스킬(Skill), 펀드 규모(FundSize), 펀드 수익률의 변동성(FundVol), 펀드의 액 티브니스 $\left(\mathrm{TR}^{2}\right)$ 등과는 양(+)의 상관관계를 가지고 있었다. 반면, Age와는 음(-)의 관계를 가지고 있었다. 그러나 이 결과는 다른 요인들을 고려하지 않은 단순 상관관계에 관한 것 이므로, 해석에 주의를 요할 필요가 있다.

\section{3. 실증분석}

\section{1 포트폴리오 구성: 복권성향 주식 편입과 펀드 특성}

어떠한 펀드들의 복권성향이 더 높은 지를 살펴보기 위해서, 본 연구에서는 펀드의 복권 성향 수준을 나타내는 $M A X 1^{H}$ 을 기준으로 한 포트폴리오 구성을 통해 특성들의 추세가 있는지 파악한다. 포트폴리오를 구성하는 자세한 방법은 다음과 같다. 첫째, 매월 말, 펀드 들의 $M A X 1^{H}$ 를 기준으로 하여, 그 익월에 오분위 포트폴리오를 구성한다. 둘째, 각 오분위 포트폴리오들의 평균적인 펀드 특성들을 $\mathrm{TNA}$ 를 기준으로 가중 평균한다.

<표 3>은 $M A X 1^{H}$ 기준 오분위 포트폴리오들의 펀드 특성들을 나타내고 있다. <표 3> 결과를 살펴보면 다음과 같이 요약할 수 있다. 첫째, 펀드의 복권성향 수준이 증가할수록, 펀드 플로우는 증가하는 경향이 있다. $M A X 1^{H}$ 가 낮은 포트폴리오에서 높은 포트폴리오로 갈수록 펀드 플로우는 단조적으로 증가하고 있으며, $M A X 1^{H}$ 가 가장 높은 포트폴리오 (High)와 $M A X 1^{H}$ 가 가장 낮은 포트폴리오(Low)의 차이는 유의하게 나타났다. 이와 같은 결과는 Agarwal et al.(2020)과도 유사하게 나타난 결과이다. 이러한 결과를 통해, 펀드 
Why do Fund Managers Increase the Lottery-Like Characteristics of the Fund?

매니저가 펀드 플로우의 증가를 위해서 펀드의 복권성향 주식에 대한 편입을 증가시키는 데 대한 인센티브를 가질 가능성이 있음을 알 수 있다. 예를 들어, 투자자들이 복권성향 주식을 많이 편입하고 있는 펀드에 대해서 더 관심을 가지고, 선호를 하여 자본을 이동시 킨다면, 펀드 매니저는 운용자산(AUM)을 증가시키기 위해서 복권성향 주식을 편입하게 될 것이다. 둘째, 펀드의 복권성향 수준과, 펀드의 성과와는 유의한 관계가 나타나지 않았다. 예를 들어, Alpha 4의 경우, $M A X 1^{H}$ 가 증가함에 따라 상승하는 모습을 보였으나 반면 5오분위 포트폴리오와 1 오분위 포트폴리오의 차이는 통계적으로 유의하게 나타나지 않았다. 즉, 펀드가 복권성향 수준을 증가시킨다고 해서 미래에 좋은 성과로 연결되는 것은 아님을 알 수 있다. 따라서 이와 같은 결과에 기초하면, 펀드의 복권성향의 증가는 펀드 매니저의 스킬 또는 종목선택 능력에 기초한다고 보기는 어려울 것이다. 반면, Berk and van Binsbergen (2015)의 방법으로 측정한 매니저의 스킬은 $M A X 1^{H}$ 가 높을수록 낮아지는 모습을 보였다.

〈표 3〉포트폴리오 구성-복권성향 주식 투자 수준에 따른 펀드 특성

펀드의 복권성향 주식 투자 수준에 따른, 펀드 특성들의 변화를 나타낸 것이다. $M A X 1^{H}$ 의 크기에 따라서, 각 월별로 펀드를 오분위 포트폴리오로 나눈다. Low부터 High까지 점차적으로 $M A X 1^{H}$ 의 크기가 커지는 포트폴리오를 나타낸다. 이후, 각 포트폴리오의 펀드 특성들을 전월의 TNA 기준으로 가중 평균하여 살펴본다. $\mathrm{DIFF}$ 는 $\mathrm{High}$ (가장 $M A X 1^{H}$ 가 높은 포트폴리오)에서 Low(가장 $M A X 1^{H}$ 가 낮은 포트폴리오)의 펀드 특성을 뺀 값이며, PVAL은 그 차이에 대한 t-test의 통계적 유의성을 나타내는 p-값이다. 변수들에 대한 자세한 설명은 <표 $1>$ 을 참고하라.

\begin{tabular}{|c|c|c|c|c|c|c|c|}
\hline & Low & Q2 & Q3 & Q4 & High & DIFF & PVAL \\
\hline$M A X 1^{H}(\%)$ & 3.809 & 4.502 & 4.646 & 4.810 & 5.277 & 1.468 & 0.000 \\
\hline$M A X 5^{H}(\%)$ & 2.296 & 2.738 & 2.834 & 2.937 & 3.208 & 0.912 & 0.000 \\
\hline$M A X 10^{H}(\%)$ & 1.431 & 1.714 & 1.775 & 1.839 & 2.002 & 0.571 & 0.000 \\
\hline$M A X 1^{\text {Fund }}(\%)$ & 1.775 & 2.073 & 2.142 & 2.178 & 2.309 & 0.534 & 0.000 \\
\hline$M A X 5^{\text {Fund }}(\%)$ & 1.148 & 1.33 & 1.379 & 1.415 & 1.501 & 0.353 & 0.000 \\
\hline MAX $10^{\text {Fund }}(\%)$ & 0.745 & 0.859 & 0.89 & 0.915 & 0.976 & 0.231 & 0.000 \\
\hline$M A X 1^{\text {Prop }}(\%)$ & 6.764 & 9.072 & 9.643 & 11.147 & 16.031 & 9.267 & 0.000 \\
\hline$M A X 5^{\text {Prop }}(\%)$ & 8.605 & 12.229 & 13.391 & 15.286 & 21.311 & 12.706 & 0.000 \\
\hline MAX $10^{\text {Prop }}(\%)$ & 11.401 & 15.927 & 17.510 & 19.623 & 25.488 & 14.087 & 0.000 \\
\hline FundFlow $(\%)$ & -0.536 & -0.866 & -0.532 & -0.340 & 1.232 & 1.768 & 0.000 \\
\hline Alpha $4(\%)$ & 0.209 & 0.280 & 0.356 & 0.342 & 0.356 & 0.147 & 0.209 \\
\hline Alpha 3(\%) & 0.299 & 0.388 & 0.516 & 0.465 & 0.488 & 0.189 & 0.124 \\
\hline $\operatorname{Rtn}(\%)$ & 0.626 & 0.684 & 0.705 & 0.742 & 0.787 & 0.161 & 0.305 \\
\hline Skill(억원) & 8.678 & 8.023 & 9.388 & 6.616 & 4.669 & -4.009 & 0.055 \\
\hline FundSize & 27.098 & 26.878 & 26.784 & 26.634 & 26.544 & -0.554 & 0.000 \\
\hline $\operatorname{Vol}(\%$, 연율화) & 17.662 & 18.836 & 18.896 & 19.053 & 19.622 & 1.960 & 0.000 \\
\hline TR2 & 2.357 & 2.457 & 2.445 & 2.410 & 2.266 & -0.092 & 0.000 \\
\hline FamSize & 28.957 & 28.687 & 28.474 & 28.226 & 28.131 & -0.826 & 0.000 \\
\hline Age & 7.462 & 7.526 & 7.527 & 7.442 & 7.148 & -0.314 & 0.000 \\
\hline Load & 0.351 & 0.569 & 0.597 & 0.619 & 0.703 & 0.352 & 0.000 \\
\hline Expense(\%) & 1.464 & 1.428 & 1.440 & 1.440 & 1.464 & 0.000 & 0.655 \\
\hline
\end{tabular}


한국증권학회지 제 50 권 6호 (2021)

셋째, 복권성향이 높은 펀드들은 주로 규모가 작고, 변동성이 크며, 덜 액티브하게 운용하고, 운용사의 규모가 상대적으로 작으며, 운용연수가 낮음을 알 수 있다. 역시 이는 Agarwal et al.(2020)이 제시한 높은 복권성향 주식에 대한 투자 비중을 보이는 유사한 결과이다.

$\mathrm{XZ}$ 펀드의 복권성향 수준에 따라서, 펀드의 스타일에도 차이가 발생한다. 부록의 <표 A.1>는 펀드의 $M A X 1^{H}$ 의 변화에 따라서, 가치, 규모, 모멘텀으로 구분한 $3 \times 3 \times 3=27$ 의 펀드 스타일이 어떻게 차이가 나는지 살펴본 것이다. 펀드 별로 각 스타일에 해당하면 1 , 아니면 0 인 더미 변수를 부여하고, 이에 대한 평균을 나타낸 것이다. 부록의 <표 A.1>의 결과를 살펴보면 주로 $M A X 1^{H}$ 가 높은 펀드들은 상대적으로 소형주 스타일, 성장주 스타일, 그리고 모멘텀 스타일에서 발견되는 경우가 많았다.

\section{2 펀드 플로우와 펀드의 복권성향 수준}

이번 절에서는 펀드의 복권성향 수준이 실제로 투자자들의 선호를 반영한 것인지를 확인 한다. 이를 위해서 아래와 같이 Sirri and Tufano(1998)의 방법론을 따라서, 펀드 플로우를 종속변수로 하고 펀드 과거 성과의 순위와 기타 통제변수를 통제한 펀드-시간 고정효과 패널 회귀분석(Fixed Effect Panel regression)을 실시한다. ${ }^{5)}$

$$
\text { FundFlow }_{i, t+1}=\alpha_{i}+\beta_{1} \text { MAX1 }_{i, t}^{H}+\beta_{2} \operatorname{LowPerf}_{i, t}+\beta_{3} \text { MidPerf }_{i, t}+\beta_{4} \text { HighPerf }_{i, t}+\text { Controls }_{i, t}+{ }_{i, t+1}
$$

$M A X 1^{H}$ 는 펀드가 편입하고 있는 종목들의 복권성향의 가중 평균, 즉, 펀드 수준에서의 복권성향을 나타내는 지표이다. 본 연구에서는 $M A X 1^{H}$ 뿐만 아니라, $M A X 5^{H}, M A X 10^{H}$ 도 펀드의 복권성향 주식 투자에 관한 변수로 회귀분석에서 포함한다. 펀드 성과의 순위는 Sirri and Tufano(1998)을 따라서 다음과 같이 변환한다. 먼저 첫째, 매월 각 펀드의 지난 12 개월 누적 스타일 조정 수익률을 기준으로 0에서 1까지 값을 가지는 백분율 순위를 산출 한다(PerfRank). 둘째, 펀드 성과의 백분율 순위를 세 부분으로 분해를 한다. 먼저 LowPerf는 $\operatorname{Min}(0.2$, PerfRank)이며, MidPerf는 Min(0.6, PerfRank-LowPerf), 마지막으로 HighPerf는 PerfRank - LowPerf - MidPerf이다. 나머지 기타 통제변수는 전월의 FundFlow, FundSize (펀드 규모), FundVol(펀드 수익률 변동성), Skill(Berk and van Binsbergen(2015)의 매니저 스킬 측도), Age(펀드 영업월수), $\operatorname{TR}^{2}$ (Amihud and Goyenko(2013)의 액티브니스 측도), FamSize(운용사 규모), 그리고 펀드가 속한 스타일의 FundFlow, 펀드 스타일 더미를 통제 하였다. 모든 통제변수는 $\mathrm{t}$ 기의 값이다. 모든 회귀분석에는 펀드와 시간 고정효과를 통제 하였으며, 이분산과 자기상관을 통제하기 위해서 펀드와 시간에 대해 군집화된 표준오차 (Double Clustered Standard Error)를 사용하였다.

5) 지면 관계 상 기재하지는 않았으나, 다른 패널 회귀분석 방법으로 통합 회귀분석(Pooled Regression)과 임의 효과(Random Effect) 회귀분석을 모두 실시하였다. 결과는 고정효과 회귀분석의 결과와 모두 유사하게 나타났다. 
Why do Fund Managers Increase the Lottery-Like Characteristics of the Fund?

〈표 4〉펀드 플로우와 펀드의 복권성향과의 관계

<표 4>는 펀드의 복권성향 주식에 대한 투자 수준이, 펀드 플로우에 어떠한 영향을 미치는지 살펴 보기 위해서, 패널 회귀분석을 실시한 것이다. 종속변수는 $\mathrm{t}+1$ 기의 펀드 플로우(FundFlow)이며, $M A X 1^{H}, M A X 5^{H}, M A X 10^{H}$ 는 펀드의 복권성향 주식에 대한 투자 수준을 나타내는 변수들이다. 예를 들어, $M A X 1^{H}$ 는 각 펀드 편입종목들의 월별 최고 수익률(Bali et al., 2011)을 가중 평균한 것이며, $M A X 5^{H}$ 와 $M A X 10^{H}$ 은 편입종목들의 월별 최고 수익률을 기록한 5 일과 10 일의 평균 수익률을 가중 평균한 것이다. 과거 성과는 Sirri and Tufano(1998)의 방식으로 펀드 성과의 백분율 순위를 세 부 분으로 분해하여 통제한다(LowPerf, MidPerf, HighPerf). 통제 변수는 과거 1개월 수익률, 과거 펀드 플로우, 매니저 스킬, 펀드 규모, 변동성, 액티브니스(Amihud and Goyenko, 2013), 스타일의 펀드 플로우, 펀드 운용연수, 펀드 보수, 수수료 더미변수, 그리고 각 펀드 스타일 구분이다. $\mathrm{t}$-통계량을 산출하는데 필요한 표준오차는 펀드와 시간을 모두 고려한 군집 표준오차(Double clustered standard error)를 적용하였다. 모든 회귀분석에는 펀드와 시간 고정효과를 통제하였다. ${ }^{* * *},{ }^{* *},{ }^{*}$ 는 각각 $1 \%$, $5 \%, 10 \%$ 유의 수준을 나타낸다.

\begin{tabular}{|c|c|c|c|}
\hline Variables & Model (1) & Model (2) & Model (3) \\
\hline$M A X 1_{i, t}^{H}$ & $0.253[2.565]^{* *}$ & & \\
\hline$M A X 5_{i, t}^{H}$ & & $0.489[2.791]^{* * *}$ & \\
\hline$M A X 10_{i, t}^{H}$ & & & $0.770[2.759]^{* * *}$ \\
\hline HighPerf $_{i, t}$ & $0.094[5.398]^{* * *}$ & $0.094[5.387]^{* * *}$ & $0.094[5.383]^{* * *}$ \\
\hline $\operatorname{MidPerf}_{i, t}$ & $0.004[2.005]^{* *}$ & $0.004[1.983]^{* *}$ & $0.004[2.000]^{* *}$ \\
\hline LowPerf $_{i, t}$ & $0.007[0.886]$ & $0.007[0.901]$ & $0.007[0.898]$ \\
\hline$R t n_{i, t}$ & $0.165[3.533]^{* * *}$ & $0.157[3.362]^{* * *}$ & $0.150[3.162]^{* * *}$ \\
\hline FundFlow $_{i, t}$ & $0.350[12.988]^{* * *}$ & $0.350[12.986]^{* * *}$ & $0.350[12.982]^{* * *}$ \\
\hline FundSize $_{i, t}$ & $0.001[2.546]^{* *}$ & $0.001[2.549]^{* *}$ & $0.001[2.549]^{* *}$ \\
\hline Skill $_{i, t}$ & $0.004[1.226]$ & $0.004[1.245]$ & $0.004[1.237]$ \\
\hline Volatility $_{i, t}$ & $0.005[0.125]$ & $-0.001[-0.020]$ & $0.00005[0.001]$ \\
\hline$T R 2_{i, t}$ & $-0.004[-1.842]^{*}$ & $-0.004[-1.860]^{*}$ & $-0.004[-1.898]^{*}$ \\
\hline Volatility $_{i, t}$ & $0.025[0.652]$ & $0.027[0.705]$ & $0.027[0.696]$ \\
\hline StyleFlow $_{i, t}$ & $0.007[0.949]$ & $0.007[0.946]$ & $0.007[0.947]$ \\
\hline $\operatorname{Age}_{i, t}$ & $-0.004[-2.422]^{* *}$ & $-0.004[-2.426]^{* *}$ & $-0.004[-2.419]^{* *}$ \\
\hline Expense $_{i, t}$ & $-3.862[-1.972]^{* *}$ & $-3.869[-1.979]^{* *}$ & $-3.873[-1.980]^{* *}$ \\
\hline $\operatorname{Load}_{i, t}$ & $-0.003[-2.030]^{* *}$ & $-0.003[-2.078]^{* *}$ & $-0.003[-2.088]^{* *}$ \\
\hline Style & YES & YES & YES \\
\hline Observations & 26,996 & 26,996 & 26,996 \\
\hline Adjusted R2 & 0.153 & 0.153 & 0.153 \\
\hline
\end{tabular}

<표 4>는 펀드의 복권성향 수준을 포함한 고정효과 패널 회귀분석 결과를 나타낸 것이다. 결과를 살펴보면 다음과 같다. 첫째, 펀드의 복권성향을 나타내는 세 가지 변수 $\left(M A X 1^{H}\right.$, $\left.M A X 5^{H}, M A X 10^{H}\right)$ 는 모두 익월의 펀드 플로우와 유의한 양(+)의 관계를 나타냈다. 즉, 펀드 수준의 복권성향이 높을수록, 투자자들은 더 많은 자본을 배분하고 있음을 알 수 있다. 이와 같은 결과는 미국의 뮤추얼 펀드를 대상으로 한 연구 결과(Agarwal et al., 2020; Akbas 
한국증권학회지 제50권 6호 (2021)

and Genc, 2020)의 결과와 일치한다. 둘째, 펀드의 과거 성과(HighPerf, MidPerf, LowPerf)들의 회귀계수는, 과거 연구들(Chevalier and Ellison, 1997; Sirri and Tufano, 1998)에서 관측되었던 펀드 플로우와 펀드 성과의 비선형적 관계를 보여준다. 예를 들어 $M A X 1^{H}$ 을 사용한 Model (1)의 경우, 과거 성과가 가장 좋은 그룹인 TopPerf의 회귀계수는 0.094인데 반해, 나머지 MidPerf와 LowPerf는 각각 0.004와 0.007로 나타나, 기존 연구와 비슷하게 펀드 성과가 펀드 플로우에 대해 비선형적인 민감도를 가지고 있는 것을 확인할 수 있었다.

〈표 5〉 펀드 플로우와 펀드 수익률의 복권성향과의 관계

펀드의 복권성향 주식에 대한 투자 비중을 나타내는 변수를 펀드의 복권성향에 대한 변수로 사용하여, 패널 회귀분석을 실시한 것이다. $M A X 1_{i, t}^{\text {Fund }}$ 는 펀드의 월별 최고 수익률이며, $M A X 5_{i, t}^{\text {Fund }}$ 와 $M A X 10_{i, t}^{\text {Fund }}$ 은 각각 한달 내 수익률이 가장 높았던 5 일(10일)의 평균을 나타낸 것이다. 종속변수는 $\mathrm{t}+1$ 기의 펀드 플로우(FundFlow)이다. 통제 변수는 과거 펀드 플로우, 매니저 스킬, 펀드 규모, 변동성, 액티브니스 (Amihud and Goyenko, 2013), 스타일의 펀드 플로우, 펀드 운용연수, 펀드 보수, 수수료 더미변수, 그리고 각 펀드 스타일 구분이다 과거 성과는 Sirri and Tufano(1998)의 방식으로 펀드 성과의 백분율 순위를 세 부분으로 분해하여 통제한(LowPerf, MidPerf, HighPerf). 통제 변수는 과거 1개월 수익률, 과거 펀드 플로우, 매니저 스킬, 펀드 규모, 변동성, 액티브니스(Amihud and Goyenko, 2013), 스타일의 펀드 플로우, 펀드 운용연수, 펀드 보수, 수수료 더미변수, 그리고 각 펀드 스타일 구분이다. $\mathrm{t}$-통계량을 산출하는데 필요한 표준오차는 펀드와 시간을 모두 고려한 군집 표준오차(Double clustered standard error)를 적용하였다. 모든 회귀분석에는 펀드와 시간 고정효과를 통제하였다. ${ }^{* * *},{ }^{* *}$, ${ }^{*}$ 는 각각 $1 \%$, $5 \%, 10 \%$ 유의 수준을 나타낸다.

\begin{tabular}{|c|c|c|c|}
\hline & Model (1) & Model (2) & Model (3) \\
\hline$M A X 1_{i, t}^{\text {Find }}$ & $0.260[1.737]^{*}$ & & \\
\hline$M A X 5_{i, t}^{\text {Find }}$ & & $0.662[2.347]^{* *}$ & \\
\hline$M A X 10_{i, t}^{F \text { Fund }}$ & & & $1.337[2.884]^{* * *}$ \\
\hline HighPerf $_{i, t}$ & $0.146[6.564]^{* * *}$ & $0.146[6.574]^{* * *}$ & $0.146[6.564]^{* * *}$ \\
\hline $\operatorname{MidPerf}_{i, t}$ & $0.001[0.416]$ & $0.001[0.349]$ & $0.001[0.295]$ \\
\hline $\operatorname{LowPerf}_{i, t}$ & $0.001[0.135]$ & $0.001[0.121]$ & $0.001[0.122]$ \\
\hline$R t n_{i, t}$ & $0.140[3.116]^{* * *}$ & $0.123[2.841]^{* * *}$ & $0.094[2.180]^{* *}$ \\
\hline Controls & YES & YES & YES \\
\hline Style & YES & YES & YES \\
\hline Obs & 26,996 & 26,996 & 26,996 \\
\hline $\operatorname{Adj} R^{2}$ & 0.154 & 0.155 & 0.155 \\
\hline
\end{tabular}

그렇다면 실제로 투자자들이 펀드의 복권성향을 어떻게 판단할 수 있는가? 투자자들이 가장 쉽게 관측할 수 있는 것은 펀드의 수익률이다. 물론 공모펀드의 편입 종목 중 비중이 높은 상위 10 개는 포털 등을 통하여 투자자들에게 공개가 되고 있고, 또한 분기별 영업보고서의 세부 운용현황에서 분기말 기준 포트폴리오를 파악할 수 있지만 이는 적시성이 있는 정보를 제공하지는 못한다. 따라서 포트폴리오 편입 종목에 대한 직접적인 정보보다는, 투자자들은 펀드 수익률로부터 복권성향의 수준을 판단함으로써 자본을 배분하게 될 것이다. 만약 투자자 
Why do Fund Managers Increase the Lottery-Like Characteristics of the Fund?

들이 펀드 수익률의 극단적인 움직임으로 펀드의 복권성향을 판단하여 더 높은 복권성향의 펀드에 많은 펀드 플로우가 유입된다면, 이는 펀드 매니저로 하여금 더 많은 높은 복권성향의 종목들을 편입하게 하는 인센티브를 제공할 것이다. 이를 확인하기 위해서, 이번엔 펀드 수익률의 복권성향을 나타내는 $M A X 1^{\text {Fund }}\left(M A X 5^{\text {Fund }}, M A X 10^{\text {Fund }}\right)$ 을 통제하여 <표 4 >와 동일한 회귀분석을 실시하였다. 〈표 5>의 결과를 정리하면, 펀드 수익률의 복권성향을 나타내는 변수들은 모두 양(+)의 회귀계수를 나타냈으며, $M A X 1^{\text {Find }}$ 제외하면 모두 $5 \%$ 유의수준에서 통계적으로 유의하게 나타났다. 즉, 펀드 투자자는 펀드 수익률의 복권성향이 높을수록, 더 많이 투자하고 있다는 것을 알 수 있다.

이처럼 펀드의 복권성향이 높은 펀드에 더 많은 펀드 플로우가 유입된다는 결과는, 투자자 들의 복권성향에 대한 선호가 반영된 것이라고 볼 수 있다. 먼저 투자자들은 펀드 수익률의 복권성향을 관측하고, 펀드 수익률의 복권성향이 높을수록 투자자들은 더 많은 자본을 배분 한다. 펀드 매니저는 투자자들의 복권성향에 대한 선호를 반영하여, 펀드에 복권성향이 높은 주식들을 편입함으로써 펀드의 전반적인 복권성향을 상승시킨다. 이는 다시 펀드 수익률의 높은 복권성향으로 나타나게 되어, 펀드 플로우가 유입되게 되는 것이다. 예를 들어, <표 $1>$ 에서 확인할 수 있듯이 $M A X 1^{H}$ 와 $M A X 1^{F \text { ind }}$ 는 0.77 의 높은 상관관계를 가지고 있다. 이러한 결과로 볼 때, 펀드 매니저는 펀드의 복권성향 $\left(M A X 1^{H}\right)$ 을 증가시킴으로써 펀드 수익률의 복권성향 $\left(M A X 1^{F \text { ind }}\right)$ 을 높게 하여 더 많은 펀드 플로우를 유입하게 하려는 인센티브가 있다고 할 수 있다고 해석할 수 있다.

추가적으로, 펀드 복권성향의 수준을 나타내는 다른 측도들을 사용했을 때에도 역시 결과가 유사하게 나타나는지를 확인한다. 본 연구에서는 복권성향이 높은 주식을 얼마나 편입하고 있는지를 나타내는 $M A X 1^{\text {Prop }}, M A X 5^{\text {Prop }}, M A X 10^{\text {Prop }}$, 그리고 LotteryIndex 를 펀드 플로우 성과 민감도 회귀분석에 펀드의 복권성향을 나타내는 변수로 포함하여 분석을 실시한다. $M A X 1^{\text {Prop }}$ 는 전체 주식을 MAX1을 기준으로 십분위(Decile)로 나누고, 각 펀드들의 상위 $8,9,10$ 십분위에 해당하는 주식의 편입 비중을 나타낸 것이다. 따라서 $M A X 1^{\text {Prop }}$ 이 높을 수록 펀드의 복권성향 주식의 비중이 높은 것이라 할 수 있다. LotteryIndex 는 Bali et al. (2018)의 방법을 따라서 산출한 지수로, 높을수록 복권성향이 높은 주식임을 나타낸다. 펀드 수준에서의 LotteryIndex 는 편입 주식들의 가중 평균을 사용하였으며, 높을수록 펀드의 복권성향이 높다는 것을 의미한다. 만약 펀드 매니저가 펀드의 복권성향을 증가시키기 위해 복권성향이 높은 주식들을 편입한다면, <표 4>의 결과와 마찬가지로 복권성향이 높은 주식의 비중이 높을수록 펀드 플로우는 증가하게 될 것이다. <표 6>의 결과를 살펴보면, $M A X 1^{\text {Prop }}$, $M A X 5^{\text {Prop }}, M A X 10^{\text {Prop }}$, LotteryIndex 의 회귀계수는 모두 유의한 양(+)의 값을 나타낸 것을 확인할 수 있다. 즉, 〈표 4>의 결과와 유사하게 펀드가 복권성향이 높은 주식들을 많이 편입 할수록, 펀드 플로우가 증가하는 것을 알 수 있다. 포트폴리오의 복권성향 수준과 펀드의 복권성향 주식들의 편입 비중과의 유의한 양 $(+)$ 의 상관관계 $\left(M A X 1^{H}\right.$ 과 $M A X 1^{\text {Prop }}$ 의 상관관계: 0.45)를 생각할 때, 펀드 매니저들은 펀드에 높은 복권성향의 주식들을 편입함으로써, 펀드의 복권성향 수준을 증가시키고 있다는 것을 알 수 있다. 
한국증권학회지 제50권 6호 (2021)

〈표 6〉펀드 플로우와 펀드의 복권성향 투자 비중과의 관계

펀드의 복권성향 주식에 대한 투자 비중을 나타내는 변수를 펀드의 복권성향에 대한 변수로 사용하여, 패널회귀분석을 실시한 것이다. $M A X 1_{i, t}^{\text {Prop }}$ 는 각 월 별로 종목들의 $M A X 1$ 를 십분위(Decile)로 분류하고, $M A X 1$ 값이 높은 $10,9,8$ 분위에 있는 주식들의 해당 펀드에서의 비중을 나타낸 것이다. 즉, 펀드가 높은 복권 성향이 짙은 종목들을 많이 편입하고 있다면, $M A X 1_{i, t}^{\text {Prop }}$ 도 역시 큰 값을 나타내게 될 것이다. $M A X 5_{i, t}^{\text {Prop }}$ 와 $M A X 10_{i, t}^{\text {Prop }}$ 는 각각 MAX5 와 MAX10 의 값이 높은 주식들의 비중을 나타낸 것이다. LotteryIndex ${ }_{i, t}$ 는 Bali et al. (2018)의 방법을 따라서 산출하였으며, 높을수록 펀드는 복권적 성향 주식에 대한 투자를 많이 하고 있는 것이다. 종속변수는 $\mathrm{t}+1$ 기의 FundFlow이다. 통제 변수는 과거 펀드 플로우, 매니저 스킬, 펀드 규모, 변동성, 액티브니스(Amihud and Goyenko, 2013), 스타일의 펀드 플로우, 펀드 운용 연수, 펀드 보수, 수수료 더미변수, 그리고 각 펀드 스타일 구분이다 과거 성과는 Sirri and Tufano (1998)의 방식으로 펀드 성과의 백분율 순위를 세 부분으로 분해하여 통제한다(LowPerf, MidPerf, HighPerf). 통제 변수는 과거 1개월 수익률, 과거 펀드 플로우, 매니저 스킬, 펀드 규모, 변동성, 액티브니스(Amihud and Goyenko, 2013), 스타일의 펀드 플로우, 펀드 운용연수, 펀드 보수, 수수료 더미변수, 그리고 각 펀드 스타일 구분이다. $\mathrm{t}$-통계량을 산출하는데 필요한 표준오차는 펀드와 시간을 모두 고려한 군집 표준오차(Double clustered standard error)를 적용하였다. 모든 회귀분석에는 펀드와 시간 고정효과를 통제하였다. ${ }^{* * *},{ }^{* *}{ }^{*}$ 는 각각 $1 \%, 5 \%, 10 \%$ 유의 수준을 나타낸다.

\begin{tabular}{lcccc}
\hline & Model (1) & Model (2) & Model (3) & Model (4) \\
\hline MAX1 $_{i, t}^{\text {Prop }}$ & $0.020[2.070]^{* *}$ & & & \\
${\text { MAX } 5_{i, t}^{\text {Prop }}}$ & $0.031[3.369]^{* * *}$ & & \\
${\text { MAX } 10_{i, t}^{\text {Prop }}}$ & & $0.029[3.484]^{* * *}$ & \\
LotteryIndex $_{i, t}$ & & & $0.037[1.998]^{* *}$ \\
HighPerf $_{i, t}$ & $0.093[5.366]^{* * *}$ & $0.091[5.238]^{* * *}$ & $0.091[5.270]^{* * *}$ & $0.094[5.419]^{* * *}$ \\
MidPerf $_{i, t}$ & $0.004[2.075]^{* *}$ & $0.004[2.020]^{* *}$ & $0.004[2.004]^{* *}$ & $0.004[2.010]^{* *}$ \\
LowPerf $_{i, t}$ & $0.007[0.880]$ & $0.007[0.895]$ & $0.007[0.880]$ & $0.007[0.906]$ \\
Rtn $_{i, t}$ & $0.171[3.590]^{* * *}$ & $0.150[3.233]^{* * *}$ & $0.138[2.954]^{* * *}$ & $0.174[3.674]^{* * *}$ \\
\hline Controls $_{\text {Style }}$ & YES & YES & YES & YES \\
Obs $_{\text {Adj R }}^{2}$ & YES & YES & YES & YES \\
\hline
\end{tabular}

\section{3 펀드의 복권성향과 펀드 매니저의 인센티브 구조}

본 절에서는 투자자들이 복권성향에 대한 선호를 반영하기 위해서 펀드의 복권성향을 증가시킨다는 결과에 대해서, 펀드 매니저의 인센티브 구조를 중심으로 추가적인 분석을 실시한다. 이를 확인하기 위해서, 다음과 같이 펀드의 복권성향의 수준에 따라 펀드 플로우에 대한 성과의 민감도가 어떻게 다르게 나타나는지를 살펴본다. 펀드 플로우와 성과는 일반 적으로 비선형적인 관계를 가지고 있다(Chevalier and Ellison, 1997; Sirri and Tufano, 1998). 만약 복권성향에 대한 투자자들의 선호가 펀드 플로우 유입에 대한 원인이라면, 복권성향이 높은 펀드 그룹에서는 복권성향이 낮은 그룹보다 펀드 플로우와 성과의 비선형 적인 관계가 더 크게 나타날 것이다. 이를 확인하기 위해서, 본 연구에서는 다음과 같은 회귀분석을 실시한다. 
Why do Fund Managers Increase the Lottery-Like Characteristics of the Fund?

$$
\begin{aligned}
& \text { FundFlow }_{i, t+1}=\alpha+\beta_{1}\left(\text { TopPerf }_{i, t} \times \operatorname{HighMAX}\right)+\beta_{2}\left(\text { MidPerf }_{i, t} \times \operatorname{HighMAX}\right)+\beta_{3}\left(\operatorname{LowPerf}_{i, t} \times \operatorname{HighMAX}\right) \\
& +\beta_{4}\left(\operatorname{TopPerf}_{i, t} \times \operatorname{MidMAX}\right)+\beta_{5}\left(\text { MidPerf }_{i, t} \times \operatorname{MidMAX}\right)+\beta_{6}\left(\operatorname{LowPerf}_{i, t} \times \operatorname{MidMAX}\right) \\
& +\beta_{7}\left(\text { HighPerf }_{i, t} \times \text { LowMAX }\right)+\beta_{8}\left(\text { MidPerf }_{i, t} \times \operatorname{LowMAX}\right)+\beta_{8}\left(\operatorname{LowPerf}_{i, t} \times \operatorname{LowMAX}\right) \\
& + \text { Controls }+\varepsilon_{i, t+1}
\end{aligned}
$$

여기서 MAX는 본 연구에서 사용하는 모든 복권성향의 주식을 나타내는 변수들 $M A X 1^{H}$, $\left.M A X 5^{H}, M A X 10^{H}\right)$ 이며, 이는 각 월별로 삼분위로 나누어 HighMAX MidMAX, LowMAX 그룹으로 나누고 더미(Dummy) 변수화 한다. 이후 HighPerf, MidPerf, LowPerf와의 교차항을 회귀분석에 독립변수로 투입하여, 펀드의 복권성향 정도가 펀드 플로우-성과 민감도에 미치는 영향이 어떻게 다르게 나타나는지를 파악한다.

만약 펀드의 복권성향이 높은 경우, 좋은 성과를 기록했을 때 얻을 수 있는 펀드 플로우의 증가를 더 증폭시킨다면, HighMAX 집단에서 HighPerf와 LowPerf의 차이에 따른 펀드 플로우의 차이가 크게 나타날 것이다. 예를 들어, HighMAX 집단에서는 HighPerf와 LowPerf의 회귀계수의 차이가, MidMAX나 LowMAX에서의 HighPerf와 LowPerf의 회귀계수의 차 이보다 더 크게 나타날 것으로 예상할 수 있다.

<표 7>은 식 (7)의 회귀분석 결과는 나타낸 것이다. 회귀분석 결과를 살펴보면 다음과 같다. 첫 번째, 앞에서의 결과와 마찬가지로 높은 성과를 기록하는 그룹(HighPerf)과 복권 성향이 높은 그룹(HighMAX)에서 높은 값의 회귀계수를 나타냈다. 둘째, 복권성향이 높은 그룹(HighMAX)에서 성과 수준에 따른 펀드 플로우에 미치는 영향의 차이가 크게 나타났다. 예를 들어, HighPerf와 LowPerf의 회귀계수 차이는 HighMAX에서 가장 크게 나타났으며, 그 차이는 통계적으로 유의하게 나타났다. 반면, 복권성향이 MidMAX인 그룹에서는 회귀 계수의 차이가 통계적으로 유의하게 나타나지 않았으며, LowMAX 그룹에서는 차이가 통 계적으로 유의하게 나타났으나, 그 차이의 정도는 HighMAX 보다 적었다.

펀드 플로우와 성과의 비선형적 관계로 인하여, 성과가 높을수록 펀드 매니저가 얻는 펀드 플로우의 증가는 같은 크기만큼의 성과가 하락했을 때 펀드 플로우의 유출보다 더 크게 나타난다. 그리고 본 연구 결과, 복권성향이 높은 펀드 그룹에서 이러한 비선형적 관계가 더 크게 나타났다. 따라서 펀드 매니저는 펀드의 복권성향을 증가시킴으로써 펀드 플로우 -성과 민감도를 더 크게 하여, 성과가 증가했을 때 더 많은 펀드 플로우를 유입하도록 할 인센티브가 있다.

그러나 이러한 펀드의 복권성향의 증가가 펀드 매니저의 전략이나 스킬에 의한 결과일 가능성도 존재한다. 만약 그렇다면, 실제로 높은 복권성향의 주식을 많이 편입할수록 펀드의 성과는 좋게 나타날 가능성이 있다. 이를 확인하기 위해서, 다음 절에서는 펀드의 높은 복권 성향 주식에 대한 투자 수준이 펀드 성과에 어떠한 영향을 끼치지는 지에 대해서 확인할 것이다. 
한국증권학회지 제50권 6호 (2021)

〈표 7〉 펀드 플로우와 펀드의 복권성향-과거 성과와의 교차항 고려

펀드의 복권성향 수준에 따라서, 펀드 매니저가 직면한 볼록한 인센티브 구조가 펀드 플로우에 미치는 영향이 어떻게 다른 지에 대해서 분석한다. 이를 위해서, 펀드의 복권성향 투자 지표를 기준으로 세 그룹으로 나누고, 다시 이 그룹을 과거 성과를 기준으로 세 그룹으로 나눠 총 9 개의 그룹을 만든다. 이후 패널 회귀분석을 활용해 펀드 플로우에 대한 민감도를 분석한다. 종속변수는 $\mathrm{t}+1$ 기의 펀드 플로우며, 복권성향 투자를 나타내는 변수들 $\left(M A X 1_{i, t}^{H}, M A X 1_{i, t}^{H}, M A X 5_{i, t}^{H}, M A X 10_{i, t}^{H}\right)$ 은 각 월말 그 크기를 기준으로 삼분위(Tertile) 분류되어 $\operatorname{HighMAX}, \operatorname{MidMAX}, \operatorname{LowMAX}$ 의 더미 변수로 변환하여 사용한다. 과거 성과 는 Sirri and Tufano(1998)의 방식을 따라서 세 부분으로 분해하여 통제한다( LowPerf, MidPerf , HighPerf ). 통제 변수는 과거 1개월 수익률, 과거 펀드 플로우, 매니저 스킬, 펀드 규모, 변동성, 액 티브니스(Amihud and Goyenko, 2013), 스타일의 펀드 플로우, 펀드 운용연수, 펀드 보수, 수수료 더미변수, 그리고 각 펀드 스타일 구분이다. $\mathrm{t}$-통계량을 산출하는데 필요한 표준오차는 펀드와 시간을 모두 고려한 군집 표준오차(Double clustered standard error)를 적용하였다. 모든 회귀분석에는 펀드와 시간 고정효과를 통제하였다. ${ }^{* * *},{ }^{* *}$, *는 각각 $1 \%, 5 \%, 10 \%$ 유의 수준을 나타낸다.

\begin{tabular}{|c|c|c|c|}
\hline & $\operatorname{MAX1}_{i, t}^{H}$ & $\operatorname{MAX} 5_{i, t}^{H}$ & $\operatorname{MAX} 10_{i, t}^{H}$ \\
\hline (1) $\operatorname{HighPerf}_{i, t} \times \operatorname{HighMAX}$ & $0.156[4.563]^{* * *}$ & $0.153[4.581]^{* * *}$ & $0.162[4.910]^{* * *}$ \\
\hline (2) $\operatorname{MidPerf}_{i, t} \times$ HighMAX & $0.005[1.330]$ & $0.007[1.654]^{*}$ & $0.005[1.336]$ \\
\hline (3) LowPerf $_{i, t} \times$ HighMAX & $-0.002[-0.242]$ & $-0.002[-0.260]$ & $-0.002[-0.279]$ \\
\hline (4) $\operatorname{HighPerf}_{i, t} \times \operatorname{MidMAX}$ & $-0.002[-0.088]$ & $-0.008[-0.353]$ & $-0.02[-1.088]$ \\
\hline (5) $\operatorname{MidPerf}_{i, t} \times \operatorname{MidMAX}$ & $0.008[2.508]^{* *}$ & $0.009[3.051]^{* * *}$ & $0.011[3.478]^{* * *}$ \\
\hline (6) $\operatorname{LowPerf}_{i, t} \times \operatorname{MidMAX}$ & $0.004[0.453]$ & $0.004[0.395]$ & $0.0003[0.034]$ \\
\hline (7) HighPerf $_{i, t} \times$ LowMAX & $0.078[2.782]^{* * *}$ & $0.086[2.939]^{* * *}$ & $0.083[2.792]^{* * *}$ \\
\hline (8) $\operatorname{MidPerf}_{i, t} \times$ LowMAX & $0.002[0.672]$ & $0.00004[0.012]$ & $-0.001[-0.265]$ \\
\hline (9) LowPerf $_{i, t} \times$ LowMAX & $0.012[1.334]$ & $0.014[1.532]$ & $0.017[1.864]^{*}$ \\
\hline \multicolumn{4}{|l|}{ Difference Test } \\
\hline Diff : (1)-(3) [p-value] & $0.158[0]^{* * *}$ & $0.155[0]^{* * *}$ & $0.164[0]^{* * *}$ \\
\hline Diff : (4)-(6) [p-value] & $-0.007[0.812]$ & $-0.012[0.639]$ & $-0.02[0.333]$ \\
\hline Diff : (7)-(9) [p-value $]$ & $0.066[0.025]^{* *}$ & $0.073[0.019]^{* *}$ & $0.066[0.036]^{* *}$ \\
\hline Controls & YES & YES & YES \\
\hline Style & YES & YES & YES \\
\hline Observations & 26,996 & 26,996 & 26,996 \\
\hline Adjusted $\mathrm{R}^{2}$ & 0.156 & 0.156 & 0.157 \\
\hline
\end{tabular}

\section{4 펀드의 복권성향과 펀드 성과, 매니저의 스킬}

본 절에서는 펀드의 복권성향이 향후 펀드의 성과에 어떠한 영향을 끼치지는 지를 확인 한다. 일반적으로 복권성향의 주식은 투자자들이 미래의 극단적인 수익률을 기대하기 때문에 수요가 증가하고, 따라서 고평가되어 낮은 수익률을 기록하게 된다(Bali et al., 2011). 펀드는 분산된 포트폴리오를 구성하기 때문에, 복권적 성향 주식에 대한 투자에서 오는 성과에 대한 부정적인 영향이 감소할 수 있다. 또한 실제로 더 액티브한 펀드들이 더 높은 성과를 
Why do Fund Managers Increase the Lottery-Like Characteristics of the Fund?

거두고 있다는 연구들(Kacperczyk et al., 2005; Cremers and Petajisto, 2009; Amihud and Goyenko, 2013)을 볼 때, 펀드의 복권성향이 증가함으로써 성과가 증가할 가능성도 있다.

본 연구에서는 펀드의 복권성향이 미래 성과에 어떠한 영향을 끼치지는 지 확인하기 위해 다음과 같은 펀드-시간 고정효과 패널 회귀분석을 실시한다.

$$
\alpha_{i, t+1}^{4 \text { Factor }}=\alpha+\beta_{1} \text { LotMeasure }_{i, t}+\beta_{2} \text { FundSize }_{i, t}+\beta_{3} \text { PoorPerf }_{i, t}+\text { Controls }_{i, t}+\varepsilon_{i, t+1}
$$

종속변수는 펀드들의 t+1기 Carhart(1997)의 4요인 모형 조정 수익률이며, Lot Measure 는 펀드의 복권성향 투자를 나타내는 변수들이다 $\left(M A X 1^{H}, M A X 5^{H}, M A X 10^{H}, M A X 1^{\text {Prop }}, M A X 5^{\text {Prop }}\right.$, $M A X 10^{\text {Prop }}$, Lottery Index) 이다. FundSize는 펀드 규모를 나타내며, PoorPerf는 펀드의 과거 성과를 나타내는 변수로, 과거 3개월 동안의 Carhart(1997) 4요인 모형 조정 수익률이 하위 십분위에 해당하면 1 , 아니면 0인 더미 변수이다. 통제 변수는 전 월의 FundFlow(펀드 플로우), Skill(매니저 스킬), FundSize(펀드 규모), $\mathrm{Vol}$ (펀드 수익률 변동성), $\mathrm{TR}^{2}$ (Amihud and Goyenko(2013)의 액티브니스 측도), FlowStyle(스타일의 펀드 플로우), Age(펀드 운용 연수), Expense (펀드 보수), $\operatorname{Load}($ 수수료 더미변수), 그리고 각 펀드 스타일을 사용하였다.

〈표 8〉 펀드의 복권성향과 미래성과: Carhart(1997) 4요인 모형

<표 8>에서는 펀드의 복권성향과 미래성과가 어떠한 관계가 있는지를 살펴본다. 이를 확인하기 위해서, 펀드의 t+1기의 Carhart(1997) 4 요인 모형 조정 수익률을 종속변수로, 그리고 펀드의 t기 복권성향 투자를 나타내는 변수들 $\left(M A X 1_{i, t}^{H}, M A X 5_{i, t}^{H}, M A X 10_{i, t}^{H}, M A X 1_{i, t}^{P_{\text {rop }}}, M A X 5_{i, t}^{\text {Prop }}, M A X 10_{i, t}^{P_{\text {rop }}}\right.$, LotteryInd $\left.{ }_{i, t}\right)$ 과 기타 통제변수들을 통제한 패널 회귀분석을 실시한다. Lot Measure 는 펀드의 복권성향 투자를 나타내는 변수들이다. FundSize $e_{i, t}$ 는 펀드 규모를 나타내며, Poor Perfi,t 는 펀드의 과거 3개월 동안의 Carhart (1997) 4요인 모형 조정 수익률이 하위 십분위에 해당하면 1, 아니면 0인 더미 변수이다. 기타 통제 변수는 과거 펀드 플로우, 매니저 스킬, 펀드 규모, 변동성, 액티브니스(Amihud and Goyenko, 2013), 스타일의 펀드 플로우, 펀드 운용연수, 펀드 보수, 수수료 더미변수, 그리고 각 펀드 스타일 구분이다. $\mathrm{t}$-통계량을 산출하는데 필요한 표준오차는 펀드와 시간을 모두 고려한 군집 표준오차 (Double clustered standard error)를 적용하였다. 모든 회귀분석에는 펀드와 시간 고정효과를 통제 하였다. ${ }^{* * *}$, ${ }^{* *}$, "는 각각 $1 \%, 5 \%, 10 \%$ 유의 수준을 나타낸다.

\begin{tabular}{|c|c|c|c|c|c|c|c|}
\hline & $M A X 1_{i, t}^{H}$ & $M A X 5_{i, t}^{H}$ & $M A X 10_{i, t}^{H}$ & $M A X 1^{\text {Prop }}$ & $M A X 5^{\text {Prop }}$ & $M A X 10^{\text {Prop }}$ & LotteryInd \\
\hline \multirow[t]{2}{*}{ Lot Measure } & 0.062 & 0.124 & 0.227 & 0.008 & 0.005 & 0.005 & 0.011 \\
\hline & [1.015] & [1.160] & [1.319] & [1.304] & {$[0.856]$} & {$[0.871]$} & [1.100] \\
\hline \multirow[t]{2}{*}{ FundSize $_{i, t}$} & $-0.027^{* * *}$ & $-0.027^{* * *}$ & $-0.027^{* * *}$ & $-0.027^{* * *}$ & $-0.027^{* * *}$ & $-0.027^{* * *}$ & $-0.028^{* * *}$ \\
\hline & {$[-3.849]$} & {$[-3.842]$} & {$[-3.833]$} & {$[-3.789]$} & {$[-3.819]$} & {$[-3.819]$} & {$[-3.884]$} \\
\hline \multirow[t]{2}{*}{ Poor Perf ${ }_{i, t}$} & $-0.004^{* * *}$ & $-0.004^{* * *}$ & $-0.004^{* * *}$ & $-0.004^{* * *}$ & $-0.004^{* * *}$ & $-0.004^{* * *}$ & $-0.004^{* * *}$ \\
\hline & {$[-8.085]$} & {$[-8.047]$} & {$[-8.015]$} & {$[-8.205]$} & {$[-8.147]$} & {$[-8.092]$} & {$[-8.121]$} \\
\hline Controls & YES & YES & YES & YES & YES & YES & YES \\
\hline Style & YES & YES & YES & YES & YES & YES & YES \\
\hline Obs & 26,996 & 26,996 & 26,996 & 26,996 & 26,996 & 26,996 & 26,996 \\
\hline Adj $R^{2}$ & 0.011 & 0.011 & 0.011 & 0.011 & 0.011 & 0.011 & 0.011 \\
\hline
\end{tabular}


한국증권학회지 제50권 6호 (2021)

<표 8>의 결과를 보면, 모든 펀드의 복권성향 지표와 미래 성과의 관계는 유의하지 않게 나타났다. 만약 펀드의 높은 복권성향이 매니저의 전략이나 스킬에 의한 것이었다면, 성과에 대해 예측력을 가지고 있을 것이다. 그러나 펀드의 복권성향을 기반으로 산출한 포트폴리오에 대한 Carhart(1997) 4 요인 회귀분석 결과는 특정한 패턴을 보이지 못하고 유의미한 결과를 나타내지 못했다. 따라서 복권성향에 대한 투자는 매니저의 종목선택 능력과 스킬에 의한 것은 아닐 가능성이 높다.

〈표 9〉펀드의 복권성향과 매니저 스킬의 관계

펀드 매니저의 스킬과 펀드의 복권성향 측도와 어떠한 관련이 있는지를 살펴본 패널 회귀분석 결과이다. 종속변수는 $M A X 1_{i, t+1}^{H}, M A X 5_{i, t+1}^{H}$, 그리고 $M A X 10_{i, t+1}^{H}$ 로, 펀드의 복권성향을 측정하는 $\mathrm{t}+1$ 기의 측도이다. $S_{k i l l}$ 은 Berk and van Binsbergen(2015)의 스킬 측도이며, PoorPerf $f_{i, t}$ 는 과거 3개월 동안의 Carhart (1997) 4요인 모형 조정 수익률이 전체 펀드 중 하위 십분위에 속하면 1 , 아니면 0 의 값을 갖는 더미 변수이다. 통제 변수는 펀드 규모, 변동성, 액티브니스(Amihud and Goyenko, 2013), 펀드 운용연수, 펀드 보수, 수수료 더미변수이다. 펀드와 시간을 모두 고려한 군집 표준오차(Double clustered standard error)를 적용하였다. 모든 회귀분석에는 펀드와 시간 고정효과를 통제하였다. ${ }^{* * *}$, ** *는 각각 $1 \%, 5 \%, 10 \%$ 유의 수준을 나타낸다.

\begin{tabular}{|c|c|c|c|}
\hline & $\operatorname{MAX1}_{i, t+1}^{H}$ & $\operatorname{MAX}_{i, t+1}^{H}$ & $\operatorname{MAX10} 0_{i, t+1}^{H}$ \\
\hline Skill $_{i, t}$ & $-0.209[-1.993]^{* *}$ & $-0.126[-1.838]^{*}$ & $-0.080[-1.757]^{*}$ \\
\hline$T R 2_{i, t}$ & $-0.186[-3.076]^{* * *}$ & $-0.090[-2.543]^{* *}$ & $-0.048[-2.179]^{* *}$ \\
\hline PoorPerf $_{i, t}$ & $-0.025[-1.037]$ & $-0.023[-1.683]^{*}$ & $-0.018[-2.128]^{* *}$ \\
\hline FundFlow $_{i, t}$ & $0.522[3.434]^{* * *}$ & $0.311[3.452]^{* * *}$ & $0.200[3.452]^{* * *}$ \\
\hline FundSize $_{i, t}$ & $-0.003[-0.303]$ & $-0.002[-0.361]$ & $-0.002[-0.445]$ \\
\hline Volatility $_{i, t}$ & $13.558[9.460]^{* * *}$ & $8.230[9.587]^{* * *}$ & $5.116[9.477]^{* * *}$ \\
\hline FamSize $_{i, t}$ & $-5.350[-4.258]^{* * *}$ & $-3.139[-4.278]^{* * *}$ & $-1.934[-4.283]^{* * *}$ \\
\hline $\operatorname{Age}_{i, t}$ & $0.047[1.230]$ & $0.025[1.105]$ & $0.014[0.996]$ \\
\hline Expense $_{i, t}$ & $24.73[0.553]$ & $12.736[0.479]$ & $7.531[0.457]$ \\
\hline $\operatorname{Load}_{i, t}$ & $0.131[3.267]^{* * *}$ & $0.081[3.351]^{* * *}$ & $0.052[3.465]^{* * *}$ \\
\hline Style & YES & YES & YES \\
\hline Observations & 26,996 & 26,996 & 26,996 \\
\hline Adjusted $\mathrm{R}^{2}$ & 0.233 & 0.246 & 0.236 \\
\hline
\end{tabular}

추가적으로 매니저의 스킬이 펀드의 복권성향에 대해 예측력을 가지고 있는지를 살펴본다. 아래와 같은 회귀분석을 실시하여 높은 복권성향 주식에 대한 투자가 매니저의 스킬에 의한 것인지 확인한다.

$$
M A X 1_{i, t+1}^{H}=\beta_{0}+\beta_{1} \text { Skill }_{i . t}+\beta_{2} \text { PoorPerf }_{i . t}+\text { Controls }+\varepsilon_{i, t+1}
$$

식 (9)는 종속변수는 $M A X 1^{H}$ 의 $\mathrm{t}+1$ 기의 값으로, Berk and van Binsbergen(2015)의 펀 드 매니저의 스킬 측도와 어떠한 관계를 가지는지를 살펴본 회귀분석을 나타낸 것이다. 
Why do Fund Managers Increase the Lottery-Like Characteristics of the Fund?

이번 회귀분석에서 관심이 있는 독립변수는 Berk and van Binsbergen(2015)의 스킬 측도 이다. 나머지 기타 통제변수는 PoorPerf, 전월의 FundFlow, FundSize(펀드 규모), Vol(펀드 수익률 변동성), Age(펀드 영업월수), $\mathrm{TR}^{2}$ (Amihud and Goyenko(2013)의 액티브니스 측도), FamSize(운용사 규모), Expense(보수), Load(수수료 더미)이다. 모든 통제변수는 t기의 값이다. 만약 스킬의 수준이 $M A X 1^{H}$ 와 관계가 있다면, $\beta_{1}$ 는 양(+)의 회귀계수를 보일 것으로 예상할 수 있다. 반면, 스킬의 수준이 $M A X 1^{H}$ 와 크게 상관이 없다면 $\beta_{1}$ 는 양(+)의 값을 보이지는 않을 것이다. 〈표 9>는 식 (10)의 회귀분석의 결과를 나타낸 것이다. 결과를 살펴 보면, $M A X 1^{H}, M A X 5^{H}, M A X 10^{H}$ 등 모든 펀드의 복권성향을 나타내는 변수에 대해서 매니저의 스킬은 음(-)의 관계를 가지고 있는 것으로 나타났다. $M A X 1^{H}$ 의 경우는 $5 \%$ 수준에서, $M A X 5^{H}$ 와 $M A X 10^{H}$ 는 $10 \%$ 유의수준에서 통계적으로 유의한 것으로 나타났다. 다시 말해서, 매니저의 스킬이 높을수록, 펀드 매니저는 펀드의 복권성향은 높지 않고 오히려 낮게 나타났다. 본 절의 결과를 정리하면, 펀드의 복권성향은 미래의 펀드 성과, 그리고 매니저의 스킬과 뚜렷한 관계를 나타내지 않았다. 따라서 지금까지의 결과로 볼 때, 편드 매니저가 복권성향이 높은 주식에 대한 투자를 통해 펀드의 복권성향을 증가시키는 이유는 복권성향에 대한 투자자 들의 선호를 반영하기 때문으로 볼 수 있다.

\section{5 펀드의 복권 성향과 위험 증가(Risk Shifting)}

펀드 매니저가 펀드의 복권성향을 증가시키는 것은 커리어 우려로 인한 위험 증가(Risk shifting)일 가능성도 있다(Brown et al., 1996; Kempf and Ruenzi, 2008; Kempf et al., 2009). 평가 직전에 복권성향 주식에 대한 편입을 늘림으로써 펀드의 복권 성향을 증가 시키고, 이를 통해 적은 확률이지만 극단적인 수익을 낼 수 있기를 기대하기 때문이다. 만약 복권성향 주식에 대한 투자 증가가 펀드 매니저의 커리어 우려에 따른 위험 증대(Risk shifting)에 의한 것이라면, 주로 매니저의 평가를 받는 연말과 분기 말에 높은 $M A X 1^{H}$ 를 기록하게 될 것이다. 만약 매니저가 극단적인 수익을 제공하는 복권성향 주식에 대한 베팅을 통해서 그 동안의 좋지 않은 성과를 만회하려고 한다면, 연말에 포트폴리오 펌핑(Portfolio pumping; Carhart et al., 2002; Hu et al., 2014)이나, 윈도우 드레싱(Window dressing; Lakonishok et al., 1991; Agarwal et al., 2014) 등의 행태가 발견되는 것과 유사하게 나타날 것이다. 이를 확인하기 위해서, 다음의 <표 $10>$ 과 같은 분석을 진행한다.

<표 10>은 펀드 수준에서의 복권 성향이 각 월별로 어떻게 다르게 나타나는지를 살펴 본 것이다. 결과를 살펴보면, 전반적으로 뚜렷한 패턴이 발견되지는 않는다. 〈표 10>의 Panel A는 각 월별로 펀드들의 포트폴리오 복권성향을 평균한 것이다. 대부분의 측도에서 12 월의 복권성향이 오히려 낮게 나타나며, 또한 12 월과 1 월의 차이는 유의하게 나타나지 않았다. 물론 연말로 갈수록 9 월에서 11 월까지는 점차 증가하는 모습을 보이나, 12 월에는 크게 하락하는 모습을 보이고 있어 포트폴리오 펌핑이나, 윈도우 드레싱의 양상과는 차이를 보인다. Panel B는 연말(10월 12월)과 나머지 월들의 펀드들의 복권성향의 차이를 살펴본 
한국증권학회지 제50권 6호 (2021)

것이다. 마지막 분기에 이르러 나머지 월의 평균 펀드의 복권성향이 증가하는 모습을 보이나, 통계적으로 큰 차이가 없는 것으로 나타났다.

\section{〈표 10〉 펀드 복권성향의 계절성}

Panel A는 펀드의 복권성향 수준을 나타내는 변수들인 $M A X 1^{H}, M A X 5^{H}, M A X 10^{H}$ 는 각 월별로 평균 하여 나타낸 것이다. Diff는 1월과 12 월 복권성향들의 차이이다. Panel B는 연도의 마지막 분기(10, 11,12 월)에 해당하는 경우의 $M A X 1^{H}, M A X 5^{H}, M A X 10^{H}$ 와 나머지 분기의 $M A X 1^{H}, M A X 5^{H}, M A X 10^{H}$ 를 비교한 것이다.

\begin{tabular}{cccc}
\hline Panel A & $M{ }_{i, t}^{H}$ & $M A X 5_{i, t}^{H}$ & $M A X 10_{i, t}^{H}$ \\
\hline (1) Jan. & 0.048 & 0.0291 & 0.0182 \\
Feb. & 0.0428 & 0.0256 & 0.0152 \\
Mar. & 0.0432 & 0.0269 & 0.0175 \\
Apr. & 0.0459 & 0.0283 & 0.0181 \\
May. & 0.0466 & 0.0278 & 0.0169 \\
Jun. & 0.0439 & 0.0263 & 0.0162 \\
Jul. & 0.047 & 0.0289 & 0.0188 \\
Aug. & 0.0468 & 0.0282 & 0.0178 \\
Sept. & 0.0476 & 0.0289 & 0.0179 \\
Oct. & 0.0521 & 0.032 & 0.0197 \\
Nov. & 0.0508 & 0.0313 & 0.0198 \\
(2) Dec. & 0.0441 & 0.0264 & 0.0163 \\
Diff : (2) - (1) & -0.0039 & -0.0027 & -0.0019 \\
p-value & 0.4434 & 0.3623 & 0.3335 \\
\hline Panel B & MAX1 $_{i, t}^{H}$ & MAX5 & MAX1 \\
\hline (3) Not Year End & 0.0458 & 0.0278 & 0.0174 \\
(4) Year End & 0.049 & 0.0299 & 0.0186 \\
Diff : (4)-(3) & 0.0033 & 0.0021 & 0.0012 \\
p-value & 0.1647 & 0.1545 & 0.2145 \\
\hline
\end{tabular}

복권성향 주식에 대한 투자 증가가 매니저의 커리어 우려에 따른 것인지를 보다 직접적 으로 살펴보기 위해서, 이번엔 펀드들의 과거 성과에 따라서 펀드의 복권성향이 다르게 나타나는지를 확인해본다. 이를 위해서, 다음과 같은 분석을 실시한다. 먼저 상반기(또는 전 분기)의 펀드들의 Carhart(1997) 4요인 조정 수익률을 기준으로 오분위(Quintile) 포트 폴리오를 구성한다. 이후 각 포트폴리오들의 복권성향 수준을 나타내는 변수들인 $M A X 1^{H}$, $M A X 5^{H}, M A X 10^{H}$ 의 하반기(또는 다음 분기) 평균을 산출한다. 최종적으로 성과가 가장 높은 포트폴리오의 평균 복권성향과 성과가 가장 낮은 포트폴리오의 평균 복권성향의 차이를 살펴 본다. 만약 저조한 성과를 만회하기 위해서 복권성향이 높은 주식들을 편입하였다면, 두 포트폴리오 간의 복권성향 차이가 유의미하게 나타날 것이다.

<표 11>은 펀드의 상반기(또는 전 분기)의 성과에 따라서 하반기(또는 다음 분기)의 펀드의 복권성향 수준이 다르게 나타나는지를 확인하는 분석 결과이다. Panel A는 상반기 성과와 하반기 복권성향 수준을 비교한 결과이며, Panel $\mathrm{B}$ 는 전 분기의 성과에 따른 다음 분기의 
Why do Fund Managers Increase the Lottery-Like Characteristics of the Fund?

평균 복권성향 수준을 나타낸 것이다. 결과를 살펴보면, Panel A와 Panel B에서 모두 펀드의 과거 성과에 따라서 이후의 복권성향이 유의미하게 변화하지는 않았다. 따라서 <표 10>과 <표 11>의 결과를 종합하면, 펀드 매니저가 포트폴리오의 복권성향을 증가시키는 것은 커리어 우려로 인한 위험 증가로 보기는 어려운 것으로 해석할 수 있다.

〈표 11〉 펀드의 상반기(또는 전 분기) 성과에 따른 하반기(또는 다음 분기) 복권성향 <표 11>에서는 펀드의 상반기(또는 전 분기)의 성과에 따라서 하반기(또는 다음 분기)의 펀드의 복권 성향 수준이 어떻게 다르게 나타나는지를 확인한다. 먼저 펀드의 상반기(또는 전분기)의 Carhart (1997) 4요인 조정 성과를 기준으로 오분위(Quintile) 포트폴리오를 구성한다. 이후 각 포트폴리오들의 복권성향 수준을 나타내는 변수들인 $M A X 1^{H}, M A X 5^{H}, M A X 10^{H}$ 의 하반기(또는 다음 분기) 평균을 산출한다. Diff는 상반기(전 분기)의 성과가 가장 높은 포트폴리오와 낮은 포트폴리오들의 평균 하반기 복권성향 차이다. Panel A는 상반기와 하반기를 비교한 결과이며, Panel B는 전 분기의 성과에 따른 다음 분기의 복권성향을 살펴본 것이다.

\begin{tabular}{cccc}
\hline Panel A: Half & MAXl $_{i, t}^{H}$ & MAX5 $_{i, t}^{H}$ & MAX10 $_{i, t}^{H}$ \\
\hline (1) Low Alpha & 0.0472 & 0.0287 & 0.0180 \\
2 & 0.0472 & 0.0287 & 0.0181 \\
3 & 0.0475 & 0.0290 & 0.0182 \\
4 & 0.0472 & 0.0288 & 0.0181 \\
(2) High Alpha & 0.0493 & 0.0300 & 0.0189 \\
Diff : (2) -(1) & 0.0020 & 0.0013 & 0.0009 \\
p-value & 0.6577 & 0.6356 & 0.6205 \\
\hline Panel B: Quarter & MAX1 $_{i, t}^{H}$ & MAX5 & MAX10 $0_{i, t}^{H}$ \\
\hline (3) Low Alpha & 0.0466 & 0.0283 & 0.0177 \\
2 & 0.0460 & 0.0281 & 0.0176 \\
3 & 0.0460 & 0.0281 & 0.0176 \\
4 & 0.0463 & 0.0282 & 0.0176 \\
(4) High Alpha & 0.0472 & 0.0287 & 0.0180 \\
Diff : (4) -(3) & 0.0006 & 0.0005 & 0.0003 \\
p-value & 0.7851 & 0.7366 & 0.6990 \\
\hline
\end{tabular}

\section{4. 추가 분석}

\section{1 펀드의 복권성향과 펀드의 인지도}

지금까지의 결과는 일관적으로 펀드의 복권성향이 높을수록 펀드 플로우는 증가한다는 것을 보여주었다. 그리고 이와 같은 결과는 펀드 투자자들의 복권성향이 높은 펀드에 대한 선호로 인해, 매니저들이 펀드의 복권성향을 증가시키기 때문으로 설명하였다. 그러나 이에 대해서는 다음과 같은 대안적 설명(Alternative explanation)이 존재한다. 투자자들이 편입 종목들의 복권성향이 높은 펀드를 선택하는 이유는, 투자자들이 복권성향을 높은 펀드를 선호하기 때문이기 보다는 그 펀드 자체가 투자자들의 눈에 잘 띄기 때문일 수도 있다. 실제로 투자자들이 투자에 관한 의사결정을 내리는데 있어서, 인지도(Visibility)는 중요한 
한국증권학회지 제 50 권 6호 (2021)

역할을 한다(Gervais et al., 2001; Barber and Odean, 2008). 만약 펀드가 복권성향 주식에 높은 비중으로 투자함으로 인하여, 펀드 수익률에서도 역시 극단적인 분포를 보일 경우, 투자자 들의 눈에 띄는 펀드가 될 수 있다. 만약 이러한 펀드의 인지도가 펀드 플로우와 펀드의 복권성향 종목에 대한 투자 수준의 관계를 결정하는 가장 중요한 요소라면, 투자자들에게 잘 알려질 수 있는 특성을 가진 펀드에서는 $M A X 1^{H}$ 의 효과가 상대적으로 적게 나타나야 할 것이다. 반면, 투자자들의 선호가 펀드 플로우와 펀드의 복권성향과의 관계를 결정 한다면, 오히려 인지도가 높은 펀드에서 $M A X 1^{H}$ 의 효과가 상대적으로 크게 나타나야 할 것이다(Akbas and Genc, 2020). ${ }^{6}$

본 연구에서는 인지도가 높은 펀드를 구분하기 위해서 총 두 가지의 지표를 사용한다. 먼저 첫 번째, 펀드의 규모와 펀드 운용사의 규모를 인지도에 대한 척도로 적용한다. 펀드와 펀드 패밀리의 규모가 큰 경우, 투자자들에게 더 잘 알려져 있으며 따라서 인지도가 더 높을 것으로 예상할 수 있다. 두 번째, 펀드 평가사의 운용사 평가 등급을 인지도에 대한 대용 변수로 사용한다. 펀드 평가사들은 여러 운용사들에 대한 정량적, 정성적 평가를 통해서 등급을 산출한다. 본 연구에서는 $\mathrm{KG}$ 제로인이 산출하는 운용사 평가 점수를 사용한다. 평가 점수가 높을수록, 펀드 투자자들에게는 알려져 있는 운용사일 가능성이 높으며, 또한 그들이 출시하는 펀드도 역시 펀드 투자자들에게 인지도가 높을 것으로 생각할 수 있다.

이를 확인하기 위해서, 인지도에 따라서 펀드의 복권 성향이 펀드 플로우에 미치는 영향이 어떻게 다르게 나타나는지를 살펴본다. 먼저 펀드의 인지도에 대한 지표로, 펀드의 규모와 운용사의 규모(AUM)를 사용한 경우의 분석을 살펴보자. 아래의 회귀분석을 통해, 펀드와 펀드 패밀리의 규모로 추정한 펀드의 인지도에 따라서, 펀드의 복권성향 정도가 펀드 플로우에 미치는 영향이 어떻게 다른 지를 파악할 수 있다.

$$
\text { FundFlow }_{i, t+1}=\alpha+\beta_{1}(M A X \times \text { Big })+\beta_{2}(M A X \times \text { Mid })+\beta_{3}(M A X \times \text { Small })+\text { Controls }+\varepsilon_{i, t+1}
$$

여기서 MAX는 본 연구에서 사용하는 모든 복권성향의 주식을 나타내는 변수들 $\left(M A X 1^{H}\right.$, $\left.M A X 5^{H}, M A X 10^{H}\right)$ 이며, 이는 각 월별로 삼분위로 나누어 HighMAX, MidMAX, LowMAX 그룹으로 나누고 더미(Dummy) 변수화 한다. 위의 식 (11)에서 Big 은 펀드 규모 또는 펀드 패밀리가 각각 전체 펀드에서 가장 높은 삼분위에 위치하는 경우를 말하며, Mid 와 Small 은 각각 그 하위 분위에 속하는 경우이다.

<표 12〉는 식 (10)의 회귀분석 결과이다. 첫째, 펀드 규모가 클수록, 펀드 플로우에 대한 펀드의 복권성향의 민감도는 더 높게 나타났다. 펀드 규모가 큰 집단(BigFund)과 펀드 복권 성향의 교차효과가, 펀드 규모가 작은 집단(SmallFund )과 펀드 복권성향의 교차효과보다

6) Akbas and Genc(2020)은 펀드 인지도에 대한 대용변수로, 모닝스타(Morningstar) 사의 'Star' 점수, Factiva에서의 펀드 패밀리에 대한 기사 수, Google Trends에서의 펀드 패밀리에 대한 검색량, 광고 및 마케팅 비용(12b-1), 펀드 패밀리 규모, 펀드 패밀리 내에서의 펀드 스타일의 수 등을 사용하였다. 
Why do Fund Managers Increase the Lottery-Like Characteristics of the Fund?

더 크게 나타나고 있다. 둘째, 운용사의 규모가 클수록, 펀드 플로우에 대한 펀드 복권성향의 민감도는 더 높게 나타났다. 운용사 규모가 큰 집단(BigFam)과 펀드 복권성향의 교차항은, 운용사 규모가 작은 집단(SmallFam)과 펀드 복권성향의 교차항보다 더 크게 나타나고 있다.

〈표 12〉 펀드 플로우-복권성향 투자 민감도: 펀드 규모와의 교차항 고려

투자자의 복권성향 주식에 대한 선호가 펀드 플로우에 미치는 효과가 투자자의 펀드에 대한 가시성 (Visibility)에 의한 것인지를 검증한다. 이를 위해서, 각 월별로 펀드 규모와 운용사 AUM(Asset Under Management)을 기준으로 세 그룹(Big, Mid, Small)으로 나누고, 펀드의 복권성향 투자 수준과 교차한 패널 회귀분석을 통해 펀드 플로우에 대한 민감도를 분석한다. 종속변수는 $\mathrm{t}+1$ 기의 FundFlow이며, $M A X 1^{H}, M A X 5^{H}$, 그리고 $M A X 10^{H}$ 은 펀드의 복권성향을 나타내는 변수들이다. 과거 성과는 펀드의 스타일 조정 성과의 백분율 순위를 세 부분으로 분해하여 통제한다(LowPerf, MidPerf, HighPerf). 통제 변수는 과거 1 개월 펀드 수익률, 과거 펀드 플로우, 매니저 스킬, 펀드 규모, 변동성, 액티브니스(Amihud and Goyenko, 2013), 스타일의 펀드 플로우, 펀드 운용연수, 펀드 보수, 수수료 더미변수이다. 펀드와 시간을 모두 고려한 군집 표준오차(Double clustered standard error)를 적용하였다. 모든 회귀분석 에는 펀드와 시간 고정효과를 통제하였다. ${ }^{* * *},{ }^{* *}$, "는 각각 $1 \%, 5 \%, 10 \%$ 유의 수준을 나타낸다.

\begin{tabular}{|c|c|c|c|c|c|c|}
\hline & \multicolumn{3}{|c|}{ FundSize } & \multicolumn{3}{|c|}{ FamSize } \\
\hline & $M A X 1_{i, t}^{H}$ & $M A X 5_{i, t}^{H}$ & $M A X 10_{i, t}^{H}$ & $M A X 1_{i, t}^{H}$ & $M A X 5_{i, t}^{H}$ & $M A X 10_{i, t}^{H}$ \\
\hline \multirow[t]{2}{*}{ MAX $\times$ BigFund } & $0.338^{* * *}$ & $0.632^{* * *}$ & $1.003^{* * *}$ & & & \\
\hline & [3.214] & [3.365] & [3.328] & & & \\
\hline \multirow[t]{2}{*}{ MAX $\times$ MidFund } & $0.247^{* *}$ & $0.479^{* * *}$ & $0.753^{* * *}$ & & & \\
\hline & {$[2.510]$} & {$[2.725]$} & {$[2.686]$} & & & \\
\hline \multirow[t]{2}{*}{ MAX $\times$ SmallFund } & 0.17 & $0.351^{*}$ & $0.542^{*}$ & & & \\
\hline & [1.627] & [1.897] & {$[1.836]$} & & & \\
\hline \multirow[t]{2}{*}{$M A X \times B i g F a m$} & & & & $0.238^{* *}$ & $0.467^{* *}$ & $0.672^{* *}$ \\
\hline & & & & {$[2.269]$} & {$[2.536]$} & [2.239] \\
\hline \multirow[t]{2}{*}{ MAX $\times$ MidFam } & & & & $0.260^{* * *}$ & $0.503^{* * *}$ & $0.775^{* * *}$ \\
\hline & & & & {$[2.599]$} & [2.818] & {$[2.658]$} \\
\hline \multirow[t]{2}{*}{ MAX $\times$ SmallFam } & & & & $0.242^{* *}$ & $0.468^{* * *}$ & $0.747^{* * *}$ \\
\hline & & & & [2.438] & [2.671] & {$[2.650]$} \\
\hline \multicolumn{7}{|l|}{ Difference test } \\
\hline Big - Small & $0.168^{* * *}$ & $0.281^{* * *}$ & $0.461^{* * *}$ & -0.004 & 0.000 & -0.075 \\
\hline $\mathrm{p}$-value & [9.756] & [9.502] & [9.363] & [0.919] & [0.996] & [0.462] \\
\hline Controls & YES & YES & YES & YES & YES & YES \\
\hline Time & YES & YES & YES & YES & YES & YES \\
\hline Style & YES & YES & YES & YES & YES & YES \\
\hline Observations & 26,996 & 26,996 & 26,996 & 26,996 & 26,996 & 26,996 \\
\hline Adjusted $\mathrm{R}^{2}$ & 0.155 & 0.155 & 0.155 & 0.155 & 0.155 & 0.154 \\
\hline
\end{tabular}

이번엔 펀드 운용사 평가 점수를 펀드의 인지도에 대한 대용변수로 본 분석을 살펴본다. 역시 운용사 평가 점수가 높은 지 낮은 지에 따라서, 펀드의 복권성향 정도가 펀드 플로우에 미치는 영향이 어떻게 다른 지를 아래와 같은 회귀분석을 통해 파악할 수 있다. 
한국증권학회지 제50권 6호 (2021)

$$
\begin{aligned}
\text { FundFlow }_{i, t+1}= & \alpha+\beta_{1}(\text { MAX } \times \text { High Fam Score })+\beta_{2}(\text { MAX } \times \text { Mid Fam Score }) \\
& +\beta_{3}(\text { MAX } \times \text { Low Fam Score })+\text { Controls }+\varepsilon_{i, t+1}
\end{aligned}
$$

〈표 13〉펀드 플로우 - 복권성향 투자 민감도: 운용사 평가점수와 교차항 고려

투자자의 복권성향 주식에 대한 선호가 펀드 플로우에 미치는 효과가 투자자의 펀드에 대한 가시성 (Visibility)에 의한 것인지를 검증한다. 이를 위해서, 각 월별로 펀드 평가사 $\mathrm{KG}$ 제로인에서 발표하는 운용사 평가 점수를 기준으로 세 그룹(High, Mid, Low)으로 나누고, 펀드의 복권성향 투자 수준과 교차한 패널 회귀분석을 통해 펀드 플로우에 대한 민감도를 분석한다. 종속변수는 $\mathrm{t}+1$ 기의 FundFlow이며, $M A X 1^{H}, M A X 5^{H}$, 그리고 $M A X 10^{H}$ 은 펀드의 복권성향을 나타내는 변수들이다. 과거 성과는 펀드의 12 개월 스타일 조정 성과의 백분율 순위를 세 부분으로 분해하여 통제한다(LowPerf, MidPerf, HighPerf). 통제 변수는 과거 1개월 펀드 수익률, 과거 펀드 플로우, 매니저 스킬, 펀드 규모, 변동성, 액티브니스(Amihud and Goyenko, 2013), 스타일의 펀드 플로우, 펀드 운용연수, 펀드 보수, 수수료 더미변수이다. 펀드와 시간을 모두 고려한 군집 표준오차(Double clustered standard error)를 적용하였다. 모든 회귀분석에는 펀드와 시간 고정효과를 통제하였다. ${ }^{* * *},{ }^{* *},{ }^{*}$ 는 각각 $1 \%$, $5 \%, 10 \%$ 유의 수준을 나타낸다.

\begin{tabular}{lccc}
\hline & \multicolumn{3}{c}{ Fund Score } \\
\cline { 2 - 4 } & $M A X 1_{i, t}^{H}$ & $M_{X} 5_{i, t}^{H}$ & $M_{X 10_{i, t}^{H}}$ \\
\hline MAX $\times$ HighScoreFam & $0.308[3.031]^{* * *}$ & $0.570[3.137]^{* * *}$ & $0.897[3.087]^{* * *}$ \\
MAX $\times$ Mid Score Fam & $0.290[2.774]^{* * *}$ & $0.537[2.928]^{* * *}$ & $0.840[2.885]^{* * *}$ \\
MAX $\times$ Low ScoreFam & $0.261[2.499]^{* *}$ & $0.491[2.659]^{* * *}$ & $0.766[2.607]^{* * *}$ \\
\hline Difference test & & & \\
High - Low[p-value] & $0.047[5.326]^{* *}$ & $0.079[5.402] * *$ & $0.132[5.861] * *$ \\
\hline Controls & YES & YES & YES \\
Style & YES & YES & YES \\
\hline Observations & 26,243 & 26,243 & 26,243 \\
Adjusted R ${ }^{2}$ & 0.150 & 0.150 & 0.150 \\
\hline
\end{tabular}

<표 13>의 결과를 보면, 운용사의 평가 점수가 높게 나타날수록, 펀드의 복권성향이 미치는 펀드 플로우에 대한 영향이 더 크게 나타났다. 즉, FamScore 와 MAX 와의 교차항의 회귀계수 중, HighFamScore 인 경우가 가장 크게 나타났다. 또한, LowFam Score 로 갈수록 그 회귀계수는 단조적으로 작게 나타났으며, $M A X 1, M A X 5, M A X 10$ 모두에서 유사하게 나타났다. 또한, HighFamScore 인 경우와 LowFamScore 인 경우의 회귀계수의 차이도 유의하게 나타났다.

본 절의 연구 결과를 정리하면, 투자자들에게 잘 알려진 펀드들, 즉, 인지도가 높은 집단에서 펀드의 복권성향 수준에 따라서 펀드 플로우가 더 크게 발생하게 되는 것으로 볼 수 있다. 만약 인지도가 펀드 플로우와 펀드의 복권성향 수준과의 관계를 설명하는 중요한 요소였다면, 인지도가 높은 집단에서는 펀드 플로우에 대한 펀드 복권성향의 민감도가 낮아야 할 것이다. 그러나 본 연구결과는 반대로 오히려 더 높게 나타났다. 따라서 펀드 플로우와 펀드 복권 성향 수준과의 관계는, 복권성향 주식에 투자함으로써 인하여 펀드의 인지도가 증가했기 때문이라고 하기 보다는, 복권성향에 대한 투자자들의 선호가 반영되어 나타난 것이라는 설명이 더 적절할 것이다. 
Why do Fund Managers Increase the Lottery-Like Characteristics of the Fund?

\section{2 강건성 분석: 복권성향에 대한 추가적인 측도 적용}

지금까지 본 연구에서는 Bali et al.(2011)의 MAX를 중심으로 주식과 펀드의 복권성향을 측정하였다. 이번 절에서는 복권성향적 주식의 대표적인 성격으로 볼 수 있는 높은 왜도와 변동성을 추가적으로 분석하여 본 연구 결과의 강건성을 확인한다. 본 연구는 왜도를 나타내는 지표로 총 왜도(Total Skewness)와 고유 왜도(Idiosyncratic Skewness)를 사용한다. 총 왜도는 각 월별 주식 수익률의 왜도를 사용한다. 고유 왜도는 각 월마다 주식 별로 Fama and French(1993)의 3요인 모형 잔차를 산출하여 그 잔차의 왜도(Skewness)를 사용한다. 변동성을 나타내는 지표로는 총 변동성(Total Volatility, TVOL)과 고유 변동성(idiosyncratic

〈표 14〉강건성 검정(펀드 플로우와 추가적인 복권성향 지표와의 관계)

펀드의 복권성향에 대한 변수로 펀드가 편입하고 있는 주식들의 왜도 및 변동성의 가중평균을 사용 하여, 패널 회귀분석을 실시한 것이다. $T S K E W_{i, t}$ 와 ISKEW $W_{i, t}$ 는 각각 주식 수익률의 총 왜도(Total Skewness)와 고유 왜도(Idiosyncratic Skewness)를 나타낸다. ISKEW 모형의 잔차를 산출하여, 그 왜도를 구한 것이다. $T S K E W_{i, t}$ 와 ISKEW $W_{i, t}$ 는 해석의 편의 상 계수에 0.01을 곱한 값을 사용한다. $T V O L_{i, t}$ 은 수익률의 총 변동성이며, $I V O L_{i, t}$ 은 고유 변동성(Idiosyncratic volatility)이다. $I V O L_{i, t}$ 도 각 월별 Fama and French(1993) 3요인 모형의 잔차를 산출하여 그 표준편차를 사용한다. 종속변수는 $\mathrm{t}+1$ 기의 FundFlow이다. 통제 변수는 과거 펀드 플로우, 매니저 스킬, 펀드 규모, 변동성, 액티브니스(Amihud and Goyenko, 2013), 스타일의 펀드 플로우, 펀드 운용연수, 펀드 보수, 수수료 더미변수, 그리고 각 펀드 스타일 구분이다 과거 성과는 Sirri and Tufano(1998)의 방식으로 펀드 성과의 백분율 순위를 세 부분으로 분해하여 통제한(LowPerf, MidPerf, HighPerf). 통제 변수는 과거 1 개월 수익률, 과거 펀드 플로우, 매니저 스킬, 펀드 규모, 변동성, 액티브니스(Amihud and Goyenko, 2013), 스타일의 펀드 플로우, 펀드 운용연수, 펀드 보수, 수수료 더미변수, 그리고 각 펀드 스타일 구분이다. $\mathrm{t}$-통계량을 산출하는데 필요한 표준오차는 펀드와 시간을 모두 고려한 군집 표준오차 (Double clustered standard error)를 적용하였다. 모든 회귀분석에는 펀드와 시간 고정효과를 통제 하였다. ${ }^{* * *},{ }^{* *}$, "는 각각 $1 \%, 5 \%, 10 \%$ 유의 수준을 나타낸다.

\begin{tabular}{|c|c|c|c|c|}
\hline & Model (1) & Model (2) & Model (3) & \\
\hline$T S K E W_{i, t}(\times 0.01)$ & $0.382[0.626]$ & & & \\
\hline $\operatorname{ISKEW}_{i, t}(\times 0.01)$ & & $0.613[0.797]$ & & \\
\hline$T_{V O L} L_{i, t}$ & & & $0.431[2.073]^{* *}$ & \\
\hline$I V O L_{i, t}$ & & & & $0.534[1.904]^{*}$ \\
\hline $\operatorname{HighPerf}_{i, t}$ & $0.157[6.721]^{* * *}$ & $0.157[6.725]^{* * *}$ & $0.156[6.680]^{* * *}$ & $0.155[6.620]^{* * *}$ \\
\hline $\operatorname{MidPerf}_{i, t}$ & $-0.0001[-0.047]$ & $-0.0001[-0.038]$ & $-0.0005[-0.184]$ & $-0.0004[-0.169]$ \\
\hline LowPerf $_{i, t}$ & $0.007[0.834]$ & $0.007[0.837]$ & $0.007[0.804]$ & $0.007[0.825]$ \\
\hline$R t n_{i, t}$ & $0.154[3.063]^{* * *}$ & $0.152[2.980]^{* * *}$ & $0.156[3.241]^{* * *}$ & $0.153[3.190]^{* * *}$ \\
\hline Controls & YES & YES & YES & YES \\
\hline Style & YES & YES & YES & YES \\
\hline Obs & 24,769 & 24,769 & 24,769 & 24,769 \\
\hline $\operatorname{Adj} R^{2}$ & 0.158 & 0.158 & 0.158 & 0.158 \\
\hline
\end{tabular}


한국증권학회지 제50권 6호 (2021)

volatility, IVOL)을 사용한다. 고유 변동성은 고유 왜도와 마찬가지로 각 월마다 주식 별로 Fama and French(1993)의 3요인 모형 잔차를 산출하여 그 잔차의 표준편차를 사용한다.

\section{〈표 15〉강건성 검정(추가적인 펀드 복권성향 지표와 미래성과)}

<표 15>에서는 펀드의 복권성향에 대한 변수로 펀드가 편입하고 있는 주식들의 왜도 및 변동성의 가중평균을 사용하여, 펀드의 복권성향과 미래성과가 어떠한 관계가 있는지를 살펴본다. 이를 확인 하기 위해서, 펀드의 t+1기의 Carhart(1997) 4 요인 모형 조정 수익률을 종속변수로, 그리고 펀드의 $\mathrm{t}$ 기 복권성향을 나타내는 변수들 $\left(T S K E W_{i, t}, I S K E W_{i, t}, T V O L_{i, t}, I V O L_{i, t}\right)$ 과 기타 통제변수들을 통제한 패널 회귀분석을 실시한다. $T S K E W_{i, t}$ 와 $I S K E W_{i, t}$ 는 각각 주식 수익률의 총 왜도(Total Skewness)와 고유 왜도(Idiosyncratic Skewness)를 나타낸다. ISKEW $W_{i, t}$ 는 각 월별 Fama and French(1993) 3요인 모형의 잔차를 산출하여, 그 왜도를 구한 것이다. $T S K E W_{i, t}$ 와 $I S K E W_{i, t}$ 는 해석의 편의 상 계수에 0.01 을 곱한 값을 사용한다. $T V O L_{i, t}$ 은 수익률의 총 변동성이며, $I V O L_{i, t}$ 은 고유 변동성(Idiosyncratic volatility)이다. $I V O L_{i, t}$ 도 각 월별 Fama and French(1993) 3요인 모형의 잔차를 산출하여 그 표준편차를 사용한다. Lot Measure 는 펀드의 복권성향 투자를 나타내는 변수들이다. FundSize $e_{i, t}$ 는 펀드 규모를 나타내며, Poor Perf $f_{i, t}$ 는 펀드의 과거 3개월 동안의 Carhart(1997) 4요인 모형 조정 수익률이 하위 십분위에 해당하면 1 , 아니면 0 인 더미 변수이다. 기타 통제 변수는 과거 펀드 플로우, 매니저 스킬, 펀드 규모, 변동성, 액티브니스(Amihud and Goyenko, 2013), 스타일의 펀드 플로우, 펀드 운용연수, 펀드 보수, 수수료 더미변수, 그리고 각 펀드 스타일 구분이다. $\mathrm{t}$-통계량을 산출하는데 필요한 표준오차는 펀드와 시간을 모두 고려한 군집 표준오차(Double clustered standard error)를 적용하였다. 모든 회귀분석 에는 펀드와 시간 고정효과를 통제하였다. ${ }^{* * *},{ }^{* *},{ }^{*}$ 는 각각 $1 \%, 5 \%, 10 \%$ 유의 수준을 나타낸다.

\begin{tabular}{lrrrr}
\hline & \multicolumn{1}{c}{ TSKEW $_{i, t}$} & \multicolumn{1}{c}{ ISKEW $_{i, t}$} & \multicolumn{1}{c}{ TVOL $_{i, t}$} & \multicolumn{1}{c}{ IVOL $_{i, t}$} \\
\hline Lot Measure & $0.042[0.111]$ & $0.367[1.155]$ & $0.076[0.527]$ & $0.139[0.765]$ \\
FundSize $_{i, t}$ & $-0.026[-3.555]^{* * *}$ & $-0.026[-3.563]^{* * *}$ & $-0.026[-3.572]^{* * *}$ & $-0.026[-3.590]^{* * *}$ \\
Poor Perf $_{i, t}$ & $-0.004[-7.674]^{* * *}$ & $-0.004[-7.681]^{* * *}$ & $-0.004[-7.623]^{* * *}$ & $-0.004[-7.620]^{* * *}$ \\
Controls & YES & YES & YES & YES \\
Style & YES & YES & YES & YES \\
Obs & 24,769 & 24,769 & 24,769 & 24,769 \\
Adj R & 0.012 & 0.012 & 0.012 & 0.012 \\
\hline
\end{tabular}

<표 14>는 펀드의 복권성향 투자에 대한 지표로 왜도와 변동성을 사용하여, 펀드 플로우와의 관계를 분석한 결과이다. 결과를 살펴보면, 고유 왜도 및 총 왜도가 높은 종목들을 보유하고 있는 경우 펀드 플로우에 큰 영향을 주지 못했다. 반면, 총 변동성과 고유 변동성이 높은 종목들을 많이 보유하고 있는 펀드의 경우, 다음달의 펀드 플로우가 증가하고 있음을 알 수 있었으며 이는 MAX로 펀드의 복권성향을 측정한 결과와 유사한 결과이다.

이번엔 편입 종목들의 왜도와 변동성을 펀드의 복권성향을 측정하는 변수로 사용하여 펀드 성과에 어떠한 영향을 미치는지에 대해 살펴본다. 〈표 15 >는 왜도와 변동성으로 측정한 펀드의 복권성향 투자 수준과 펀드의 성과와의 관계를 살펴보는 식 (8)의 회귀분석을 수행한 결과이다. 결과를 살펴보면, <표 8>에서의 결과와 같이 모든 복권성향 측도에서 성과와 유의미한 관계를 발견할 수 없었다. 따라서 펀드의 복권성향을 측정하는 다른 변수들을 적용한 경우에도 역시 기존과 유사한 결과를 얻었으며, 강건함을 확인하였다. 
Why do Fund Managers Increase the Lottery-Like Characteristics of the Fund?

\section{5. 결론}

본 연구는 펀드 매니저들이 어떠한 동기로 펀드의 복권성향을 증가시키는지, 그리고 그 펀드의 복권성향은 향후 펀드의 성과에 어떠한 영향을 끼치게 되는지에 대해서 분석하였다. 이를 파악하기 위해서, 본 연구는 2005년 1월부터 2018년 9월까지의 국내 시장을 대상으로 한 주식형 공모펀드를 대상으로 연구를 진행하였다. Agarwal et al.(2020), Akbas and Genc(2020) 등의 방법을 따라 직전 월의 가장 높은 일 수익률로 정의된 MAX1를 복권성향 주식을 판단하는 측도로 삼고 분석을 실시하였다. 먼저, 본 연구는 투자자들의 선호가 펀드에 대한 펀드 플로우에 반영되는 것으로 가정하고, 펀드의 복권성향 수준이 펀드 플로우에 어떠한 관계가 있는지에 대해서 분석하였다. 그리고 펀드의 복권성향 수준이 펀드 성과에 대해 예측력을 가지고 있는지에 대해서 분석을 실시하였다.

본 연구의 결과는 다음과 같다. 첫째, 펀드 매니저가 펀드의 복권성향을 높게 유지하는 것은 투자자들의 선호를 반영하여 포트폴리오를 구성하는 것이라 볼 수 있다. 펀드 플로우에 대한 패널 회귀분석 결과, 편입 종목들의 복권성향을 가중평균한 펀드 전체의 복권성향이 높을수록, 펀드 플로우는 상승하는 결과를 보였다. 이는 투자자들이 관측하기 쉬운 펀드 수익률의 복권성향이 높은 경우에도 마찬가지였다. 또한 복권성향이 높은 펀드 그룹에서의 펀드 플로우-성과의 볼록한 관계는 복권성향이 낮은 펀드 그룹보다 더 크게 나타났다. 즉, 복권성향이 높을수록 같은 크기의 성과 증가가 있을 때 더 많은 펀드 플로우 유입이 나타 나고 있는 것이다. 따라서 이와 같은 결과는 복권성향이 높은 주식들에 대한 투자자들의 선호가 펀드를 선택하는 데에도 반영된 결과로 해석할 수 있으며, 펀드 매니저는 이러한 선호를 반영하여 높은 복권성향의 주식들을 편입하여 펀드의 복권성향을 증가시키는 것으로 볼 수 있다. 둘째, 펀드의 복권성향 수준은 펀드 성과에 대해 유의한 예측력을 보이지 못했다. 추가적으로 매니저 스킬이 높을수록, 익월의 펀드의 복권성향은 감소하였다. 따라서 매니저는 자신의 스킬이나 특별한 전략에 의해서 펀드의 복권성향을 증가시키는 것은 아닌 것으로 나타났다. 셋째, 펀드 매니저가 복권성향을 증가시키는 현상은 커리어 우려에 의한 것이라는 가설로 설명하기는 어려웠다. 펀드 매니저의 평가가 집중되는 연말이나 분기말에 펀드의 복권 성향이 높게 나타나는 계절성은 발견되지 않았다. 또한 상반기(또는 전 분기)의 펀드 성과와 하반기(또는 다음 분기)의 펀드의 복권성향도 유의한 관계를 보이지 못했다. 마지막으로, 본 연구 결과에 대한 여러 대안적 설명에 대한 추가 분석을 진행하였으나, 결과적으로 본 연구의 결과를 지지하는 것으로 나타났다.

펀드의 복권성향의 증가 또는 펀드 매니저들의 복권성향 주식에 대한 투자는 투자자들의 이해와 밀접하게 이어질 수 있는 이슈이며, 따라서 이에 대한 연구는 투자자 보호의 측면 에서도 중요하다. 본 연구는 펀드 매니저들이 펀드의 복권성향을 증가시키거나, 감소시키는 모습이 어떠한 동기에 의해서 발생하는지에 대해서 연구하고, 펀드의 복권성향 증가가 실제로 펀드 성과에 어떠한 영향을 끼쳤는지를 파악했다는 점에서 시사점을 제공한다. 즉, 펀드 매니저들이 펀드의 복권성향을 증가시키는 것은 고객의 선호를 반영한 것인지, 매니저의 스킬에 의한 것인지, 커리어 우려로 인한 위험 증가의 한 형태인지 등을 파악할 수 있었다. 또한 복권성향을 증가시키는 행위는 펀드의 성과에 유의미한 변화를 가져오지 않음을 알 수 있었다. 
한국증권학회지 제50권 6호 (2021)

\section{References}

Agarwal, V., G. D. Gay, and L. Ling, 2014, Window Dressing in Mutual Funds, The Review of Financial Studies, Vol. 27 (11), pp. 3133-3170 .

Agarwal, V., L. Jiang, and Q. Wen, 2020, Why do Mutual Funds Hold Lottery Stocks?, Journal of Financial and Quantitative Analysis, pp. 1-47.

Akbas, F., and E. Genc, 2020, Do Mutual Fund Investors Overweight the Probability of Extreme Payoffs in the Return Distribution?, Journal of Financial and Quantitative Analysis, Vol. 55 (1), pp. 223-261.

Amihud, Y., and R. Goyenko, 2013, Mutual fund's $\mathrm{R}^{2}$ as Predictor of Performance, The Review of Financial Studies, Vol. 26 (3), pp. 667-694.

Bali, T. G., S. J. Brown, S. Murray, and Y. Tang, 2017, A lottery-demand-based Explanation of the Beta Anomaly, Journal of Financial and Quantitative Analysis, Vol. 52 (6), pp. 2369-2397.

Bali, T. G., N. Cakici, and R. F. Whitelaw, 2011, Maxing out: Stocks as Lotteries and the cross-section of Expected Returns, Journal of Financial Economics, Vol. 99 (2), pp. 427-446.

Bali, T. G., D. Hirshleifer, L. Peng, and Y. Tang, Attention, Social Interaction, and Demand for lottery-like Stocks. Working Paper, Georgetown McDonough School of Business, 2018, https://ssrn.com/abstract=3343769.

Barber, B. M., X. Huang, and T. Odean, 2016, Which Factors Matter to Investors? Evidence from Mutual Fund Flows, The Review of Financial Studies, Vol. 29 (10), pp. 26002642.

Barber, B. M. and T. Odean, 2008, All That Glitters: The Effect of Attention and News on the Buying Behavior of Individual and Institutional Investors, The Review of Financial Studies, Vol. 21 (2), pp. 785-818.

Barberis, N., and M. Huang, 2008, Stocks as Lotteries: The Implications of Probability Weighting for Security Prices, American Economic Review, Vol. 98 (5), pp. 20662100 .

Berk, J. B., and R. C. Green, 2004, Mutual Fund Flows and Performance in Rational Markets, Journal of Political Economy, Vol. 112 (6), pp. 1269-1295.

Berk, J. B., and J. H. van Binsbergen, 2015, Measuring Skill in the Mutual Fund Industry, Journal of Financial Economics, Vol. 118 (1), pp. 1-20.

Berk, J. B., and J. H. van Binsbergen, 2016, Assessing Asset Pricing Models Using Revealed Preference, Journal of Financial Economics, Vol. 119 (1), pp. 1-23.

Berk, J. B., and J. H. van Binsbergen, 2017, How Do Investors Compute the Discount Rate? 
Why do Fund Managers Increase the Lottery-Like Characteristics of the Fund?

They Use the CAPM. Financial Analysts Journal, Vol. 73 (2), pp. 25-32.

Boyer, B., T. Mitton, and K. Vorkink, 2009, Expected Idiosyncratic Skewness, The Review of Financial Studies, Vol. 23 (1), pp. 169-202.

Brown, K. C., W. V. Harlow, and L. T. Starks, 1996, Of Tournaments and Temptations: An Analysis of Managerial Incentives in the Mutual Fund Industry, The Journal of Finance, Vol. 51 (1), pp. 85-110.

Brunnermeier, M. K., C. Gollier, and J. A. Parker, 2007, Optimal Beliefs, Asset Prices, and the Preference for Skewed Returns, American Economic Review, Vol. 97 (2), pp. $159-165$.

Carhart, M. M., 1997, On Persistence in Mutual Fund Performance, The Journal of Finance, Vol. 52 (1), pp. 57-82.

Carhart, M. M., R. Kaniel, D. K. Musto, and A. V. Reed, 2002, Leaning for the Tape: Evidence of Gaming Behavior in Equity Mutual Funds. The Journal of Finance, Vol. 57 (2), pp. 661-693.

Chevalier, J., and G. Ellison, 1997, Risk Taking by Mutual Funds as a Response to Incentives, Journal of Political Economy, Vol. 105 (6), pp. 1167-1200.

Cremers, K. M., and A. Petajisto, 2009, How Active is Your Fund Manager? A New Measure that Predicts Performance, The Review of Financial Studies, Vol. 22 (9), pp. 3329-3365.

Del Guercio, D., and P. A. Tkac, 2002, The determinants of the flow of funds of managed portfolios: Mutual Funds vs. Pension Funds, Journal of Financial and Quantitative Analysis, Vol. 37 (4), pp. 523-557.

Doran, J. S., D. Jiang, and D. R. Peterson, 2011, Gambling Preference and the New Year Effect of Assets with Lottery Features, Review of Finance, Vol. 16 (3), pp. 685-731.

Edelen, R. M., O. S. Ince, and G. B. Kadlec, 2016, Institutional Investors and Stock Return Anomalies, Journal of Financial Economics, Vol. 119 (3), pp. 472-488.

Evans, R. B., 2010, Mutual Fund Incubation, The Journal of Finance, Vol. 65 (4), pp. 15811611.

Fama, E. F., and K. R. French, 1993, Common Risk Factors in the Returns on Stocks and Bonds, Journal of Financial Economics, Vol. 33 (1), pp. 3-56.

Gervais, S., R. Kaniel, and D. H. Mingelgrin, 2001, The High-Volume Return Premium, The Journal of Finance, Vol. 56 (3), pp. 877-919.

Goldie, B. A., T. R. Henry, and H. Kassa, 2019, Does MAX Matter for Mutual Funds?, European Financial Management, Vol. 25 (4), pp. 777-806.

Han, B., and A. Kumar, 2013, Speculative Retail Trading and Asset Prices, Journal of Financial and Quantitative Analysis, Vol. 48 (2), pp. 377-404. 
한국증권학회지 제 50 권 6호 (2021)

Harvey, C. R., and A. Siddique, 2000, Conditional Skewness in Asset Pricing Tests, The Journal of Finance, Vol. 55 (3), pp. 1263-1295.

Hu, G., R. D. McLean, J. Pontiff, and Q. Wang, 2014, The Year-end Trading Activities of Institutional Investors: Evidence from Daily Trades, The Review of Financial Studies, Vol. 27 (5), pp. 1593-1614.

Kacperczyk, M., C. Sialm, and L. Zheng, 2005, On the Industry Concentration of Actively Managed Equity Mutual Funds, The Journal of Finance, Vol. 60 (4), pp. 1983-2011.

Kempf, A., and S. Ruenzi, 2007, Tournaments in Mutual-Fund Families, The Review of Financial Studies, Vol. 21 (2), pp. 1013-1036.

Kempf, A., and S. Ruenzi, 2008, Family Matters: Rankings within Fund Families and Fund Inflows, Journal of Business Finance \& Accounting, Vol. 35 (1-2), pp. 177-199.

Kempf, A., S. Ruenzi, and T. Thiele, 2009, Employment Risk, Compensation Incentives, and Managerial Risk Taking: Evidence from the Mutual Fund Industry, Journal of Financial Economics, Vol. 92 (1), pp. 92-108.

Kumar, A., 2009, Who Gambles in the Stock Market?, The Journal of Finance, Vol. 64 (4), pp. 1889-1933.

Lakonishok, J., A. Shleifer, and R. H. Thaler, 1991, Window Dressing by Pension Fund Managers, The American Economic Review, Vol. 81, pp. 227-231.

Mitton, T., and K. Vorkink, 2007, Equilibrium Underdiversification and the Preference for Skewness, The Review of Financial Studies, Vol. 20 (4), pp. 1255-1288.

Sirri, E. R., and P. Tufano, 1998, Costly Search and Mutual Fund Flows, The Journal of Finance, Vol. 53 (5), pp. 1589-1622.

Song, I., and Y. K. Park, 2019, Penny Stocks: A Handy Tool for Enhancing Fund Performance?. Asia-Pacific Journal of Financial Studies, Vol. 48 (4), pp. 445-475.

Stein, R., Are Mutual Fund Managers Good Gamblers?, Working Paper, University of $\mathrm{Ne}^{-}$ braska-Lincoln, 2019, https://ssrn.com/abstract=2919410.

Pástor, L., R. F. Stambaugh, and L. A. Taylor, 2015, Scale and Skill in Active Management, Journal of Financial Economics, Vol. 116 (1), pp. 23-45.

Tversky, A., and D. Kahneman, 1992, Advances in Prospect Theory: Cumulative Representation of Uncertainty, Journal of Risk and Uncertainty, Vol. 5 (4), pp. 297-323. 
Why do Fund Managers Increase the Lottery-Like Characteristics of the Fund?

\section{〈부록〉}

〈표 A.1〉 포트폴리오 구성: 복권성향 주식 투자 수준에 따른 스타일 변화

펀드의 복권성향 주식에 대한 투자 $\left(\mathrm{MAX1}^{H}\right)$ 의 변화에 따라서 펀드 스타일이 어떻게 다르게 나타 나는지를 살펴본 것이다. 먼저 $\mathrm{MAX1}$ 의 크기에 따라서, 각 월별로 펀드를 오분위 포트폴리오로 나눈다. $\mathrm{DIFF}$ 는 $\mathrm{High}$ (가장 $\mathrm{MAX1}^{H}$ 가 높은 포트폴리오)에서 $\mathrm{Low}$ (가장 $\mathrm{MAX1}^{H}$ 가 낮은 포트폴리오)의 펀드 특성을 뺀 값이며, PVAL은 그 차이에 대한 t-test의 통계적 유의성을 나타내는 $\mathrm{p}$-값이다. 펀드 스타일은 다음과 같이 분류한다. 첫째, 각 펀드별로 지난 36개월 동안의 Carhart(1997) 4요인 회귀 분석을 실시하고, 규모, 가치, 모멘텀 요인에 대한 회귀계수를 산출한다. 둘째, 각 월별로, 회귀계수들의 크기를 기준으로 삼분위로 분류한다(Low, Mid, High). 셋째, 이후 독립적으로 구성된 각 요인 별 삼 분위 포트폴리오를 서로 교차시켜 $3 \times 3 \times 3=27$ 개의 스타일을 만들고 각 펀드별로 스타일을 부여 한다.

\begin{tabular}{lrrrrrrr}
\hline \multicolumn{1}{c}{ MAX1 } & \multicolumn{1}{c}{ Q1 } & \multicolumn{1}{c}{ Q2 } & \multicolumn{1}{c}{ Q3 } & \multicolumn{1}{c}{ Q4 } & \multicolumn{1}{c}{ Q5 } & \multicolumn{1}{c}{ DIFF } & \multicolumn{1}{c}{ PVAL } \\
\hline BIG_GROWTH-DOWN & 0.025 & 0.023 & 0.023 & 0.024 & 0.011 & -0.014 & 0 \\
BIG_GROWTH_MID & 0.03 & 0.04 & 0.034 & 0.032 & 0.02 & -0.01 & 0.02 \\
BIG_GROWTH_UP & 0.023 & 0.039 & 0.039 & 0.049 & 0.04 & 0.017 & 0.002 \\
BIG_NEUTRAL_DOWN & 0.026 & 0.024 & 0.023 & 0.017 & 0.01 & -0.016 & 0 \\
BIG_NEUTRAL_MID & 0.032 & 0.042 & 0.048 & 0.039 & 0.025 & -0.007 & 0.179 \\
BIG_NEUTRAL_UP & 0.019 & 0.03 & 0.031 & 0.028 & 0.023 & 0.004 & 0.273 \\
BIG_VALUE_DOWN & 0.049 & 0.033 & 0.02 & 0.013 & 0.006 & -0.043 & 0 \\
BIG_VALUE_MID & 0.017 & 0.022 & 0.027 & 0.021 & 0.006 & -0.011 & 0 \\
BIG_VALUE_UP & 0.013 & 0.014 & 0.018 & 0.016 & 0.008 & -0.005 & 0.036 \\
MID_GROWTH_DOWN & 0.009 & 0.021 & 0.019 & 0.017 & 0.01 & 0.001 & 0.746 \\
MID_GROWTH_MID & 0.031 & 0.032 & 0.032 & 0.036 & 0.023 & -0.008 & 0.123 \\
MID_GROWTH_UP & 0.025 & 0.048 & 0.047 & 0.05 & 0.032 & 0.007 & 0.116 \\
MID_NEUTRAL_DOWN & 0.017 & 0.023 & 0.027 & 0.019 & 0.006 & -0.011 & 0 \\
MID_NEUTRAL_MID & 0.031 & 0.036 & 0.034 & 0.041 & 0.026 & -0.005 & 0.202 \\
MID_NEUTRAL_UP & 0.027 & 0.059 & 0.074 & 0.049 & 0.041 & 0.013 & 0.008 \\
MID_VALUE_DOWN & 0.051 & 0.025 & 0.018 & 0.015 & 0.008 & -0.043 & 0 \\
MID_VALUE_MID & 0.024 & 0.021 & 0.021 & 0.02 & 0.012 & -0.012 & 0 \\
MID_VALUE_UP & 0.016 & 0.02 & 0.027 & 0.028 & 0.024 & 0.009 & 0.025 \\
SMALL_GROWTH_DOWN & 0.016 & 0.019 & 0.012 & 0.018 & 0.028 & 0.012 & 0.004 \\
SMALL_GROWTH_MID & 0.011 & 0.019 & 0.014 & 0.015 & 0.041 & 0.03 & 0 \\
SMALL_GROWTH_UP & 0.015 & 0.03 & 0.038 & 0.046 & 0.098 & 0.083 & 0 \\
SMALL_NEUTRAL_DOWN & 0.019 & 0.017 & 0.01 & 0.009 & 0.015 & -0.005 & 0.059 \\
SMALL_NEUTRAL_MID & 0.015 & 0.016 & 0.017 & 0.026 & 0.019 & 0.005 & 0.135 \\
SMALL_NEUTRAL_UP & 0.015 & 0.029 & 0.039 & 0.034 & 0.04 & 0.025 & 0 \\
SMALL_VALUE_DOWN & 0.099 & 0.053 & 0.038 & 0.025 & 0.018 & -0.081 & 0 \\
SMALL_VALUE_MID & 0.034 & 0.023 & 0.031 & 0.024 & 0.02 & -0.014 & 0.001 \\
SMALL_VALUE_UP & 0.021 & 0.021 & 0.022 & 0.035 & 0.057 & 0.036 & 0 \\
\hline
\end{tabular}

